\title{
REPRODUCTION IN THE ZEBRA MARE EQUUS BURCHELLI ANTIQUORUM FROM THE KRUGER NATIONAL PARK
}

\author{
G. L. SMUTS \\ National Parks Board of Trustees \\ Private Bag X404 \\ Skukuza \\ 1350
}

Abstract - Reproductive characteristics of Burchell's zebra mares are described using data collected from captive and free ranging animals and the reproductive tracts of 310 mares shot during a game cropping campaign. The pubertal interval in zebra mares ranges from age 16 to 22 months, succesful mating occurring for the first time at 23 months of age. Full reproductive capacity is attained at three years. Zebra mares are seasonally polyoestrous, with an average of $85 \%$ of all mating and foaling occurring during the wet summer months (October to March). The gestation period is about 375 days and peak mating and foaling occurred in December or January for four successive years. The reproductive cycle of the zebra mare is synchronised with photoperiod. Rainfall and grass growth flushes, however, have a profound effect on the initiation of mating activity and on irregularities in relative monthly conception percentages. Mares have their first postpartum oestrus at eight to nine days with heat lasting approximately six days. Foals are normally weaned at 11 months of age (range $=$ nine to 16 months). Conception rate varied between 64 and $91 \%$ (mean $=79 \%$ ). Rainfall and the concomitant increase in green vegetation was found to affect annual conception rate, with regular summer rainfall being more important than total summer precipitation. Graafian follicles attain diameters exceeding $30 \mathrm{~mm}$ during prooestrous, all ovulations eventually taking place via the ovarian fossa. Multiple ovulations are rare but secondary ovulations occur between the 70th and 110th day of pregnancy. The left ovary is more active than the right and transuterine migrations of ova are common. No twin conceptions or instances of reproductive senescence were recorded. Five ovarian abnormalities were found, all incapable of causing permanent sterility. 


\section{Introduction}

The study on reproduction in the zebra mare forms part of an investigation involving growth, reproduction and population characteristics of Burchell's zebra (Equus burchelli antiquorum) in the Kruger National Park (KNP) (Smuts 1974a). The purpose of the study was to collect general information on reproduction in the mare but particularly on aspects such as puberty and sexual maturity, the seasonal reproductive cycle and factors influencing conception rate.

Analysis of data has indicated that, as with the stallion (Smuts 1976), reproductive characteristics of the Burchell's zebra mare are similar to the domestic equids. Zebra mares are seasonally polyoestrous with an average of $85 \%$ of all mating and foaling occurring during the summer months.

\section{Material and Methods}

The collection of reproductive data was confined to the Central District (5 $560 \mathrm{sq} . \mathrm{km}$ ) of the KNP. Here free ranging zebra were observed with $11\left(4 \sigma^{3} \sigma^{\circ}+7 q\right.$ q $)$ also being captured and retained in captivity for varying periods of time. Captive animals provided data on gestation period, the heat cycle and lactation. Field observations were limited to counts designed to determine the foaling season while certain behavioural aspects were noted whenever the opportunity presented itself. From July 1969 to June 1973, 48 monthly foaling season counts were undertaken between the first and fifth day of each month. These counts were conducted from a vehicle and the routes were designed so as to sample representative sections of the range of both the Satara (sedentary) and the Eastern Boundary (migratory) zebra sub-populations (Smuts 1972). During each count 300 to $600 \mathrm{~km}$ were covered until a random sample of 1000 zebra had been counted and classified into the following age classes: newly born foals; foals 1 week to 1 month old; foals 2 to 12 months old; immatures and sub-adults plus adults.

Between May 1969 and November 1972 the reproductive tracts of 310 mares, shot during a cropping campaign, were collected. Generally the entire reproductive tract was removed for examination with each ovary being marked left or right, excised and placed into bottles containing 10\% formalin. Fallopian tubes were dissected out and their convolutions freed from the mesosalpinx. Their total length, from the uterine to the abdominal ostium, was then determined. In non-pregnant mares uterine and vaginal measurements (Fig. 1) were taken. Other data routinely collected included: (i) Mass of the udder and a description of the state of activity, (ii) whether the mare had a foal at foot and its age, (iii) the side of implantation (pregnant mares), (iv) foetal measurements and sex (Smuts 1975), (v) mass of the uterus and its contents.

Embryonic and foetal gonads were also collected and fixed together with the ovaries of the corresponding mare. Once the ovaries and foetal gonads were properly fixed all attachments were dissected away (ovarian 


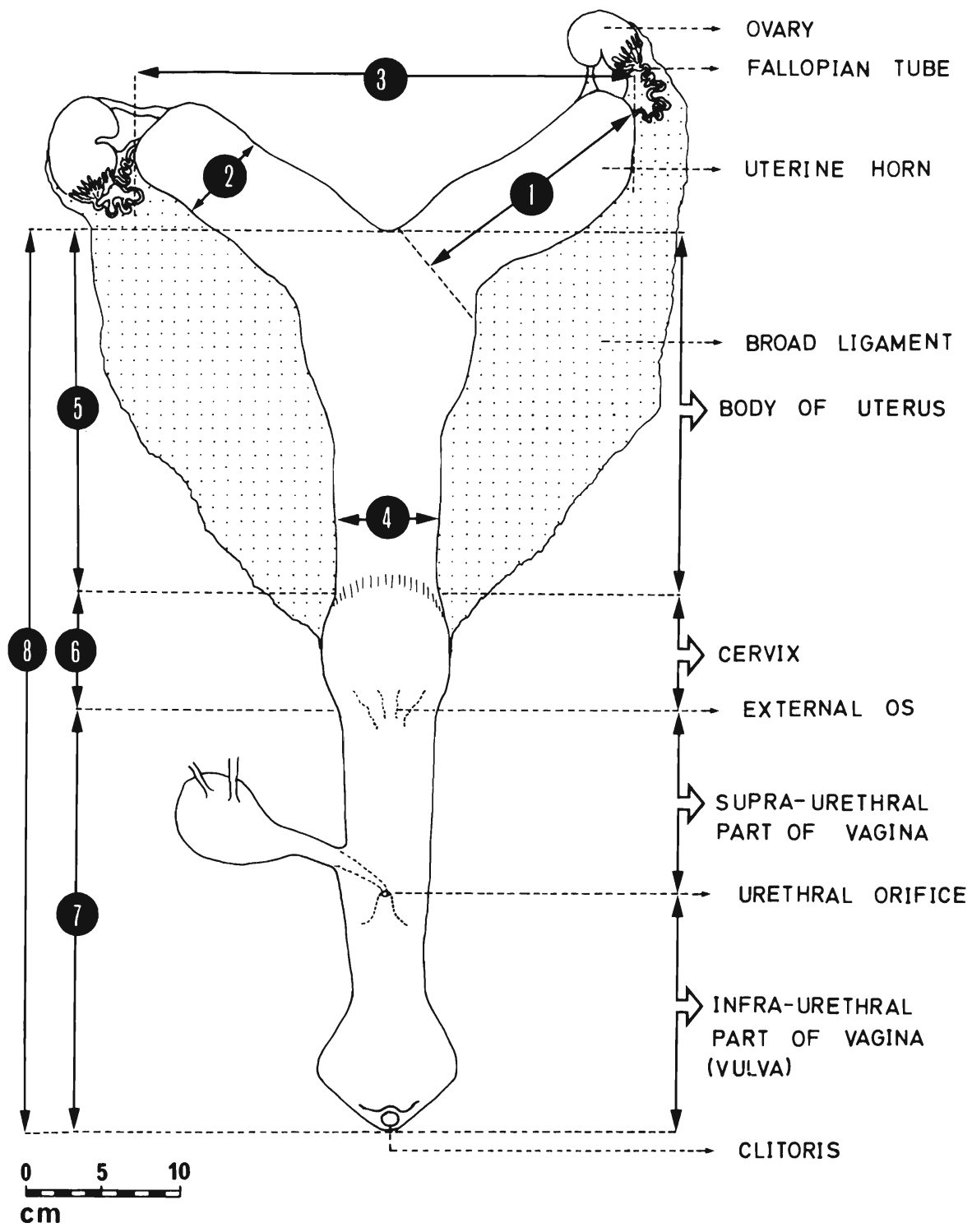

Fig. 1. Scale diagram of the reproductive tract of a Burchell's zebra mare illustrating the measurements ( 1 to 8 ) routinely made on the tracts of non-pregnant mares. These measurements were taken by laying the tract on a smooth, wet surface and allowing it to settle into position.

ligament and mesovarium or epididymis) and the mass of each gland determined. Ovaries were later sectioned macroscopically so that follicles and corpora lutea could be counted. Cutting was done using a large scalpel and sections 2 to $4 \mathrm{~mm}$ thick were run in a vertical plane from the free to the attached border of each ovary. The maximum 
diameter of all visible follicles or corpora lutea were measured and, to avoid double counts, the coagulated liquor folliculi of each follicle was scraped out as it was counted. The ages of all zebra were determined as described by Smuts (1972 and 1974b).

\section{Results}

\section{Social organisation}

Socially Burchell's zebra populations consist of coherent family and stallion groups with family groups comprising one adult stallion (leader stallion) and one to five mares and their foals. The aspects are described in more detail by Klingel (1965) and Smuts (1974a and 1976).

\section{The oestrous cycle}

The oestrous cycle of Burchell's zebra may be divided into the following phases:

Pro-oestrus - the phase immediately preceding oestrus or the preliminary period of refusal and delay. This is characterised by a marked increase in the activity of the reproductive organs (ovaries, uterus and vagina).

Oestrus - the period of acceptance of the male. The mare "stands" for the stallion.

Metoestrus - the phase succeeding oestrus when reproductive activity subsides (the luteal phase).

Dioestrus - the quiescent period between heat cycles.

Anoestrus - the prolonged period of sexual rest during which ovarian function is largely in abeyance (the non-breeding season) and the uterus is small and anaemic (Benesch and Wright 1957). This is also the normal state of the filly until at adolescence the primary sex organs begin to function.

In captive animals oestrus lasted for about six days with copulation occurring on numerous occasions during each day. The foal heat (first postpartum oestrus) occurred eight and nine days after birth $(\mathrm{n}=2)$. Supporting these observations was the ovary of an adult mare with a two week old foal at foot, which contained a very recent corpus haemorrhagicum.

\section{Gestation period, pregnancy and birth}

One gestation period, recorded from the last observed copulation, was obtained from a captive mare. This gave a period of 396 days. At six to seven months before birth, pregnancy is manifest in the external appearance of the mare, the abdomen being slightly enlarged when viewed posteriorly. After this period foetal growth is rapid (Smuts 1975), with the mass of the pregnant uterus and its contents doubling during the last two months of pregnancy (29 to $58 \mathrm{~kg}$ ). At this stage a mare's 
movements become ungainly due to the unstabilizing and swaying motion of the heavy abdominal region.

Having given birth, mares frequently eat part of the afterbirth. The afterbirth for two mares which foaled in captivity had masses of 3,2 and 3,3 kilogram.

\section{Mother-foal relationships}

In Burchell's zebra the mother-foal bond is close, particularly during the first few weeks of life. At this early stage the mare assumes a protective role and will not allow any other zebra to approach her foal too closely. During their first few weeks of life, foals are not yet fully imprinted with the mother image and when forcibly separated from their mothers, will follow most large moving objects, even a vehicle. During this period foals characteristically stay very close to their mothers, usually right up against their sides. Mares with young foals tend to be more wary than other members of the group and will move off at the first sign of danger.

\section{Lactation and weaning.}

In three different captive pregnant mares, without foals at foot, it was found that a visible increase in size of the mammary gland (udder) is initiated at an average of 35 days before parturition, actual results being 31,36 and 38 days. Milk can only be expressed from the mammary gland after parturition. Just prior to parturition the udder attains a mass of $2,5 \mathrm{~kg}$ while the mass of the inactive udder during the first trimester of the pregnancy varies between about 200 and $500 \mathrm{~g}$ in mares without a foal at foot. During the first week after parturition and if the foal is alive and suckling, the mass of the udder decreases to about 2,2 kilogram. As the foal gets older it drinks less and the gland gradually subsides to its involuted state. Should a mare lose her foal soon after birth, the udder increases in size as it becomes engorged with milk and in two cases udders were found to have a mass of 4,5 kilogram. In similar cases with captive mares, the udder was found to involute within about five days after loss of the foal.

In cases where it was possible to examine the udder of a mare and accurately determine the age of her foal, it was noted that the earliest weaning occurred when the foal was 11 months old. Comparing the activity of the mammary gland with the stage of a subsequent pregnancy indicates that lactation and suckling continue, if the foal remains alive, until one or two months prior to parturition. Should a mare not conceive soon after foaling she normally continues to lactate until her foal is over a year old. One captive mare continued to lactate until her foal was 16 months old. In this mare, lactation ended six months prior to the birth of her next foal. 


\section{Development of the uterus and vagina}

Uterine and vaginal measurements taken from a series of maiden mares and non-pregnant adult mares are given in Table 1 and 2 respectively. Last-mentioned measurements were only taken from mares in which complete involution of the uterus had taken place. The actual measurements recorded are illustrated in Fig. 1. The length of the fallopian tubes in adult mares varied from 15,5 to $24,5 \mathrm{~cm}$ with an average of $19,8 \mathrm{~cm}(\mathrm{n}=19)$. The adult dimension is usually attained by 2,5 years of age ( $n=7$ immature and sub-adult mares).

Table 1

Uterine and vaginal dimensions for seven young maiden Burchell's zebra mares collected in the Central District of the Kruger National Park

\begin{tabular}{|c|c|c|c|c|c|c|c|c|c|}
\hline \multirow{4}{*}{$\begin{array}{c}\text { Ref. No. } \\
\text { on } \\
\text { Fig. } 1 \\
1\end{array}$} & \multirow{2}{*}{\multicolumn{2}{|c|}{ Measurement $(\mathrm{cm})$}} & \multicolumn{7}{|c|}{ Age (Years) } \\
\hline & & & \multirow{3}{*}{$\begin{array}{c}1 \\
9,3 \\
9,7\end{array}$} & \multirow{3}{*}{$\begin{array}{l}\frac{1 \frac{1}{2}}{8,8} \\
7,6\end{array}$} & \multirow{3}{*}{$\begin{array}{r}1 \frac{1}{2}-2 \\
7,0 \\
6,8\end{array}$} & \multirow{3}{*}{$\begin{array}{r}1 \frac{1}{2}-2 \\
7,0 \\
6,8\end{array}$} & \multirow{3}{*}{$\begin{array}{c}2 \frac{1}{2} \\
10,7 \\
12,5\end{array}$} & \multirow{3}{*}{\begin{tabular}{c}
\multicolumn{1}{c}{3} \\
9,6 \\
11,5
\end{tabular}} & \multirow{3}{*}{$\begin{array}{r}3 \frac{1}{4} \\
9,8 \\
11,2\end{array}$} \\
\hline & Length of & Left & & & & & & & \\
\hline & uterine horn & Right & & & & & & & \\
\hline \multirow[t]{2}{*}{2} & Width of & Left & - & 5,0 & - & - & 一 & 4,9 & 4,8 \\
\hline & uterine horn & Right & - & 3,5 & - & - & - & 4,8 & 4,9 \\
\hline 3 & \multicolumn{2}{|c|}{$\begin{array}{l}\text { Spread of uterine } \\
\text { horn }\end{array}$} & 16,4 & 16,0 & 14,0 & 12,8 & 22,5 & 23,3 & 20,7 \\
\hline 4 & \multicolumn{2}{|c|}{$\begin{array}{l}\text { Width of body of } \\
\text { uterus }\end{array}$} & 3,2 & 5,8 & 5,1 & 5,7 & 6,8 & 6,6 & 6,5 \\
\hline 5 & \multicolumn{2}{|c|}{$\begin{array}{l}\text { Length of body of } \\
\text { uterus }\end{array}$} & 11,6 & 12,1 & 6,3 & 7,6 & 8,9 & 17,8 & 14,1 \\
\hline 6 & \multicolumn{2}{|c|}{ Length of cervix } & 3,6 & 4,0 & 5,4 & 4,7 & 6,3 & 4,2 & 4,0 \\
\hline 7 & \multicolumn{2}{|c|}{$\begin{array}{l}\text { Length of vagina } \\
\text { and vulva }\end{array}$} & 28,1 & 17,1 & 28,3 & 25,6 & 30,5 & 23,8 & 24,0 \\
\hline 8 & \multicolumn{2}{|c|}{$\begin{array}{l}\text { Total length (vagina } \\
\text { and body of uterus) }\end{array}$} & 43,8 & 37,8 & 42,0 & 40,0 & 45,8 & 50,0 & 45,8 \\
\hline
\end{tabular}

\section{Development of the ovaries}

As in the domestic horse (Hammond and Wodzicki 1941), the ovary of adult zebra mares is characteristically bean-shaped. However, during both prenatal and postnatal life a number of clear developmental changes take place in the ovary. In particular these changes concern the gross morphology of the gland with simultaneous histological changes. To illustrate the growth in mass process as it occurs in the foetal gonad, 
Uterine and vaginal dimensions for adult Burchell's zebra mares collected in the Central District of the Kruger National Park

\begin{tabular}{|c|c|c|c|c|c|c|c|}
\hline $\begin{array}{c}\text { Ref. No } \\
\text { on } \\
\text { Fig. } 1\end{array}$ & \multicolumn{2}{|c|}{ Measurement $(\mathrm{cm})$} & $\mathrm{n}$ & Max. & Min. & Mean & S.D. \\
\hline 1 & $\begin{array}{l}\text { Length of uterine } \\
\text { horn }\end{array}$ & $\begin{array}{l}\text { Left } \\
\text { Right }\end{array}$ & $\begin{array}{l}10 \\
10\end{array}$ & $\begin{array}{l}14,5 \\
17,1\end{array}$ & $\begin{array}{l}8,0 \\
8,6\end{array}$ & $\begin{array}{l}12,1 \\
12,2\end{array}$ & $\begin{array}{l}2,1 \\
2,5\end{array}$ \\
\hline 2 & $\begin{array}{l}\text { Width of uterine } \\
\text { horn }\end{array}$ & $\begin{array}{l}\text { Left } \\
\text { Right }\end{array}$ & $\begin{array}{l}9 \\
9\end{array}$ & $\begin{array}{l}7,0 \\
6,2\end{array}$ & $\begin{array}{l}4,1 \\
4,1\end{array}$ & $\begin{array}{l}5,3 \\
5,3\end{array}$ & $\begin{array}{l}0,9 \\
0,7\end{array}$ \\
\hline 3 & \multicolumn{2}{|c|}{ Spread of uterine horn } & 10 & 33,0 & 18,9 & 25,7 & 5,1 \\
\hline 4 & \multicolumn{2}{|c|}{ Width of body uterus } & 10 & 8,5 & 3,9 & 7,0 & 1,5 \\
\hline 5 & \multicolumn{2}{|c|}{ Length of body of uterus } & 10 & 20,6 & 13,3 & 17,5 & 2,2 \\
\hline 6 & \multicolumn{2}{|l|}{ Length of cervix } & 10 & 5,8 & 4,0 & 4,9 & 0,2 \\
\hline 7 & \multicolumn{2}{|c|}{ Length of vagina and vulva } & 9 & 30,9 & 20,5 & 24,4 & 2,9 \\
\hline 8 & \multicolumn{2}{|c|}{$\begin{array}{l}\text { Total length (vagina and } \\
\text { body of uterus) }\end{array}$} & 9 & 54,6 & 47,8 & 51,5 & 2,4 \\
\hline
\end{tabular}

Fig. 2 has been included. Both foetal ovaries and testes have been used as the pattern of growth is basically the same. Fig. 3 on the other hand, illustrates postnatal growth of the ovary. In Fig. 4 ovaries have been arranged in a series from a 70-day foetus (1) to a fully mature adult with a large growing corpus luteum (10). The arrangement clearly shows how the foetal ovary initially increases in size (2) and then regresses (3) until after birth (4) and how, in the postnatal ovary, developing follicles deform the gland as they increase in size (5 to 10). Growth of follicles in the adult ovary, however, will be discussed in a later section. Gross changes in the size and histology of zebra foetal ovaries are discussed by Smuts (1974a).

The shape and size of the postnatal ovary is largely determined by follicular development in the stroma (Smuts 1974a). This development in turn varies considerably from animal to animal but in general the characteristic almost round shape observed at birth changes to flat and then to the bean-shape of the mature adult. The shape at birth (Fig. 4), with the characteristic area of germinal tissue (later ovarian fossa), changes within the first few months of life so that at approximately one to two months of age the ovary assumes a flat shape, i.e. the free border is no longer the apex of a hump but is almost flat and is gradually assuming the characteristic features of the ovarian fossa. As follicles 


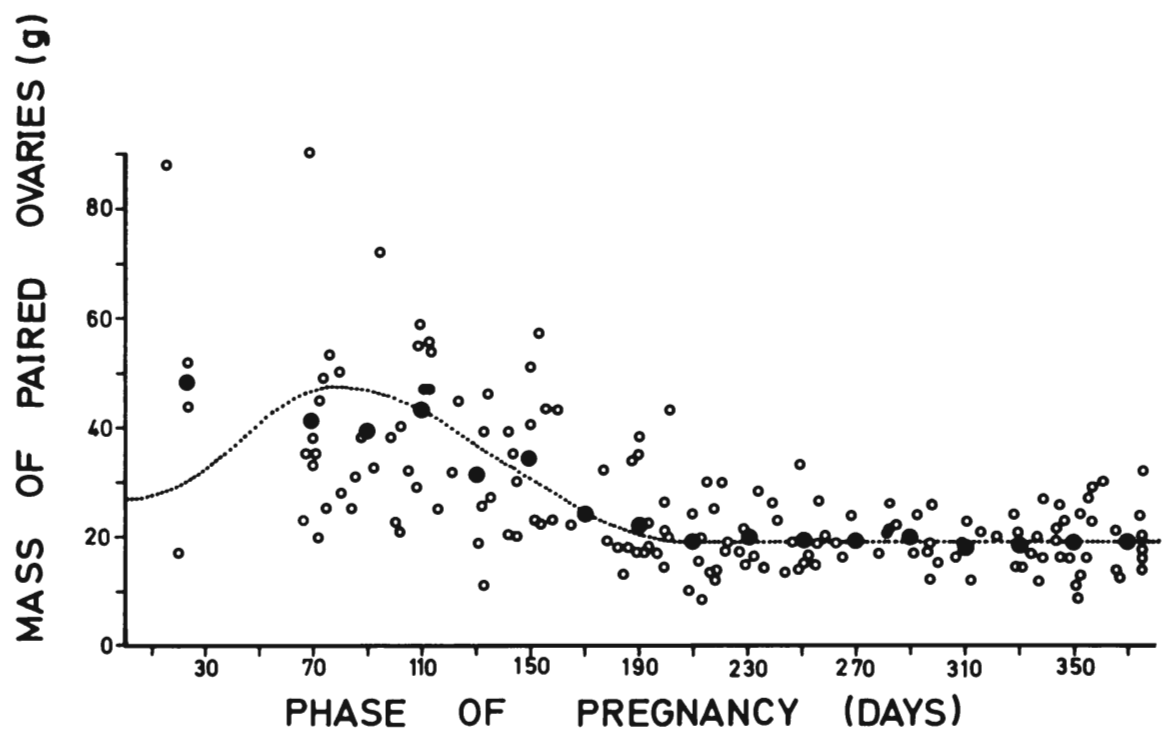

Fig. 2. Growth in mass with age of foetal gonads from Burchell's zebra. ( $n=43$ pairs of foetal ovaries and 41 pairs of foetal testes). The curve was fitted by eye.

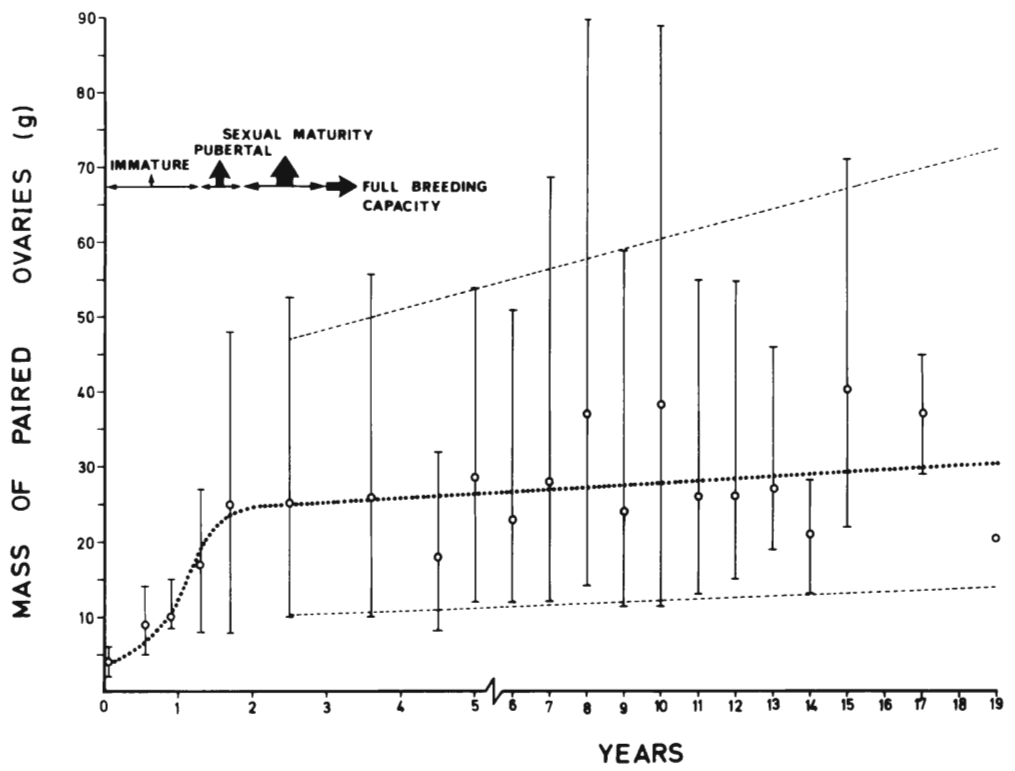

Fig. 3. Postnatal growth in mass with age of Burchell's zebra ovaries. The sample includes ovaries from 257 mares between birth and 19 years of age. The vertical lines indicate total variation within each age class and the two almost horizontal broken lines, the average maximum and average minimum mass for paired ovaries from mature mares. The broken lines thus illustrate average mass of the inactive ovary (lower line) and average mass of the ovary when at maximum activity (upper line). Average data on puberty and sexual maturity are also illustrated. The curve was fitted by eye. 


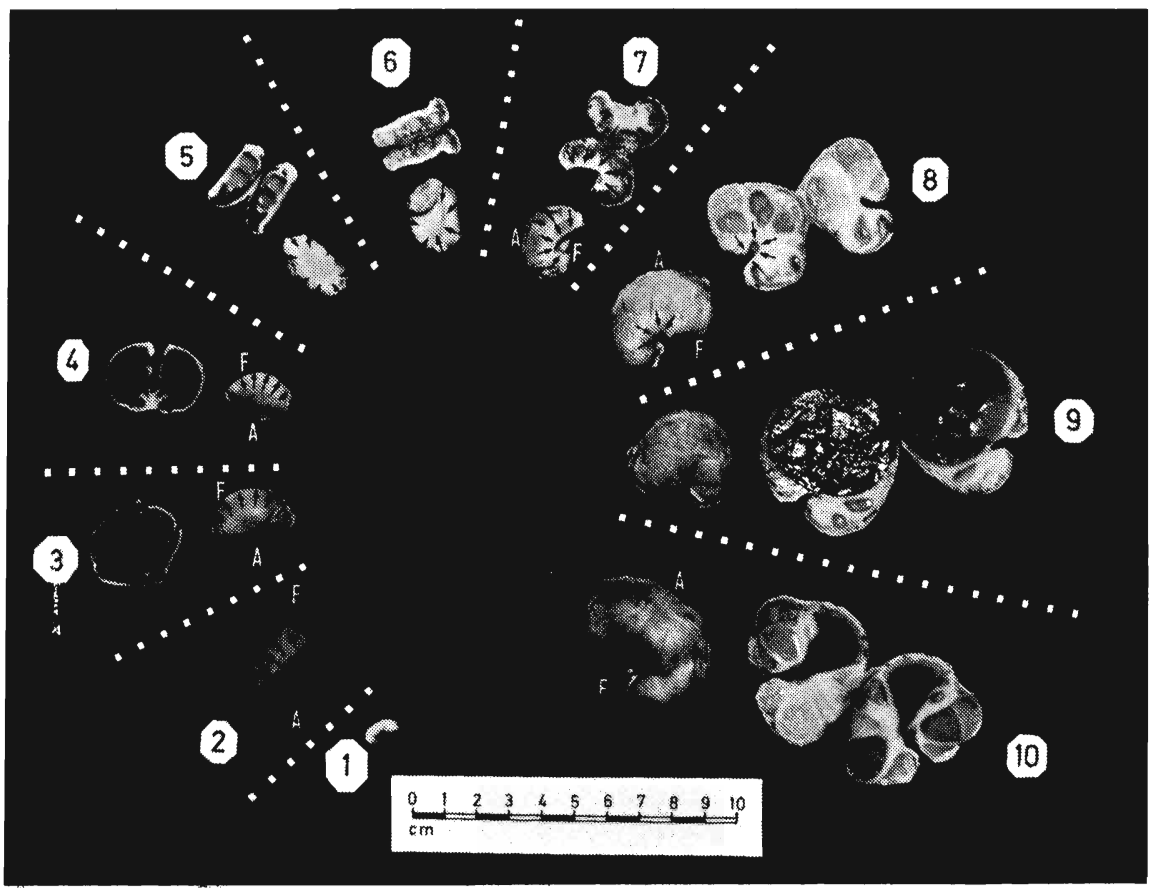

Fig. 4. Growth and development of the Burchell's zebra ovary from the prenatal through the early postnatal to the adult stage. Development proceeds in a clockwise direction from (1) to (10). With the exception of (1) and (2) all ovaries are arranged in pairs (each pair being from the same animal) those in the outer circle having been sliced down the centre from the free to the attached border and then opened out. With the exception of (5) and (6) the ovaries of the inner circle are arranged with their attached (mesovarial) borders in the same direction e.g. the edge of (2) closest to the "scale" is the attached border while the edge of (10) furthest from the "scale" is the attached border. In the case of (5) and (6) the free borders are dorsally situated. The small arrows present on ovaries (2) of the inner circle illustrate development of the ovarian fossa.

(Scale - cm). Legend: (1) = 70-day foetus; $(2)=255$-day foetus; $(3)=375$-day (full term) foetus; $(4)=$ newly born foal; $(5)=2$-month old foal; $(6)=6$-month old foal; $(7)=9$-month old foal; $(8)=1 \frac{1}{2}$-year old mare; $(9)=2 \frac{1}{2}$-year old (sexually mature) mare; $(10)=3 \frac{1}{2}$-year old adult mare; $(A)=$ attached border of ovary; $(F)=$ free border of ovary.

start enlarging below the germinal epithelium, the ovary is slowly inverted due to the relatively greater development of the medullary region in comparison to the cortical area. The latter area, now partially surrounded by, but not easily distinguishable from the medulla, forms the ovarian fossa. This fossa has normally been formed by the time the mare is three to six months old but becomes more pronounced in older mares with growing follicles. 
In Burchell's zebra there is undoubtedly a very clear morphological and histological difference between the free border with its contained ovarian fossa and the rest of the ovary. This is especially the case in young mares where the difference is visible even externally with the naked eye. In all mares ovulation was found to occur from the ovarian fossa and never from any other region of the free surface of the ovary as was found by Kupfer (1928) in young horse and donkey mares. In the zebra there definitely appears to be a predestined area, the ovarian fossa, for the ovulation of follicles.

In adult zebra mares the involuted anoestrous ovary has an approximate mass of $10 \mathrm{~g}$ (range $=5$ to $18 \mathrm{~g}$ ) while the active ovary has a mass of $30 \mathrm{~g}$ (range $=10$ to $55 \mathrm{~g}$ ) (Fig. 3). The size and shape of the ovary is as variable as its mass and during the late stages of pregnancy it is generally long and narrow, and tapers from the tubal to the uterine extremity (Fig. 8). During pro-oestrus, oestrus, metoestrus and during pregnancy the shape and size varies according to the size of the developing follicles and corpora lutea.

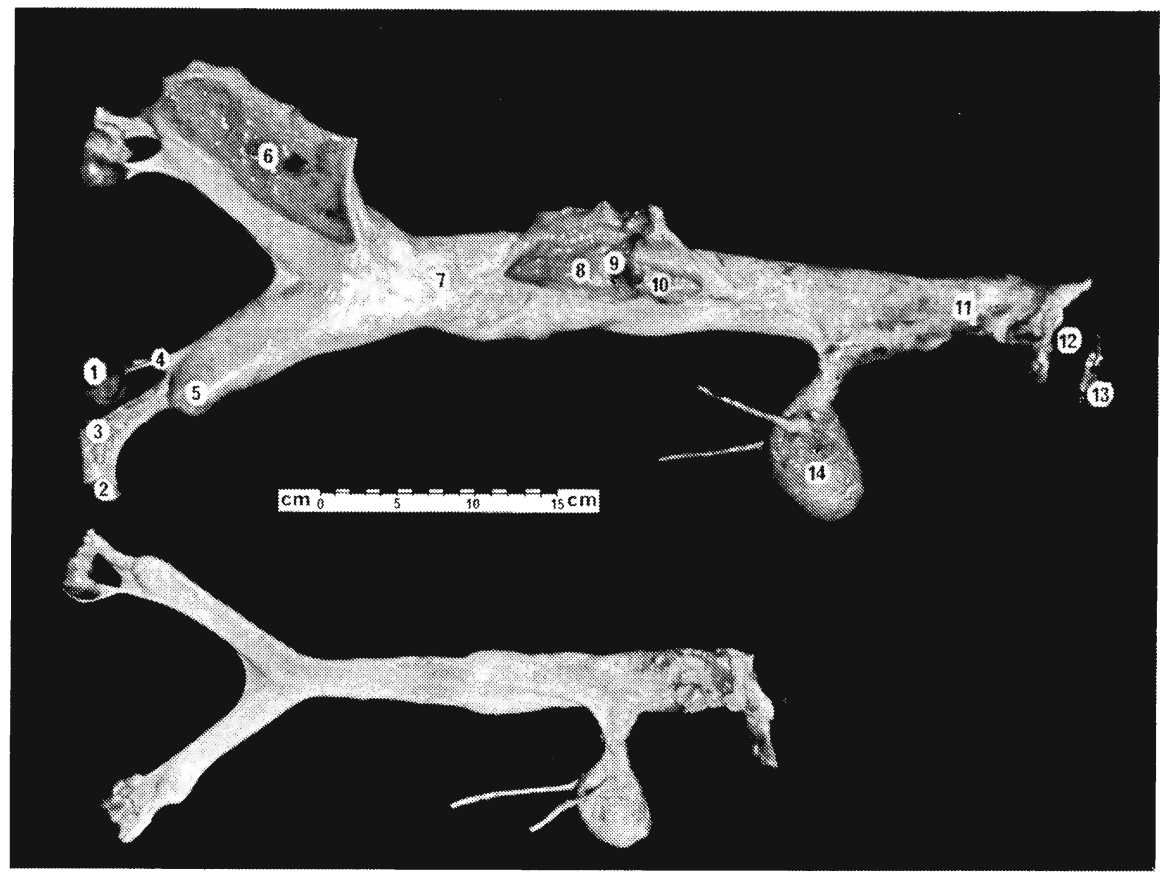

Fig. 5. Difference in size between the tubular genitalia of a sexually mature (2⿺辶year old) Burchell's zebra mare (upper) and an immature yearling. Both tracts are viewed ventrally. Legend: $(1)=$ right ovary; $(2)$ = fimbriated end of fallopian tube; (3) = fallopian tube enclosed by mesosalpinx; $(4)=$ ovarian ligament; $(5)=$ right uterine horn; (6) $=$ uterine horn slit open; (7) = body of uterus; $(8)=$ cervix; (9) $=$ external os of cervix; (10) = supra-urethral part of vagina (vagina proper); (11) = infra-urethral part of vagina (vulva); (12) = labium of vulva; $(13)=$ clitoris in ventral commissure of vulva; $(14)=$ bladder. 


\section{Puberty and sexual maturity}

Figure 5 illustrates the differences in size between the tubular genitalia of a sexually mature (2,5 year old) zebra mare and an immature yearling while development of the ovaries is illustrated in Fig. 3. Accepting that ovulation is an indication of puberty (Donovan 1966), sections of ovaries from $40 \mathrm{KNP}$ mares between the ages of one and three years proved that the first ovulations occur at 1,5 to two years of age ( 2 mares out of a sample of 8 ).

In one case a mare estimated to be 21 months old, was found to be in the process of aborting a $473 \mathrm{~g}$ foetus. Since the foetus was estimated to be four months old, the mare must have ovulated and conceived when approximately 17 months old.

In the older age classes ( 2 to 3 years) ( $n=24$ mares) it was found that there was a gradual increase in the number of ovulating mares and by 3,25 to 3,5 years of age $(n=12$ mares) all had ovulated as indicated by the presence of a developing or regressing corpus luteum.

The conception rates for a sample of 58 young mares from a number of age classes are given in Table 3. Considering the two pregnant mares in the two- to 2,5 year old group and the four in the 2,5 to three-year old group and calculating when they conceived (method of Huggett and Widdas 1951 - see Smuts 1975) the following ages of first conception were obtained: 23, 24, 27, 29, 31 and 32 months respectively. Averaging these gives a first conception age of 28 months.

\section{Table 3}

Age-specific conception rates for a sample of 58 young Burchell's zebra mares collected in the Central District of the Kruger National Park between 1969 and 1972

\begin{tabular}{c|c|c|c|c}
\hline $\begin{array}{c}\text { Age Class } \\
\text { (Years) }\end{array}$ & $\begin{array}{c}\text { No. in } \\
\text { Sample }\end{array}$ & $\begin{array}{c}\text { No. } \\
\text { Pregnant }\end{array}$ & $\begin{array}{c}\text { Conception } \\
\text { Rate of Age } \\
\text { Class (\%) }\end{array}$ & Pregnancy \\
\hline 1 & 3 & 0 & 0 & - \\
\hline $1-1 \frac{1}{2}$ & 8 & 0 & 0 & - \\
\hline $1 \frac{1}{2}-2$ & 8 & 1 & 12,5 & aborting mare \\
\hline $2-2 \frac{1}{2}$ & 9 & 2 & 22,2 & normal pregnancies \\
\hline $2 \frac{1}{2}-3$ & 15 & 4 & 26,7 & normal pregnancies \\
\hline $3-3 \frac{1}{2}$ & 15 & 11 & 73,3 & normal pregnancies \\
\hline
\end{tabular}


The mating season is that period of the year when mammals mate and has often been referred to as the time when the females of a species come into oestrus. The foaling season on the other hand is that portion of the year during which the majority of young are born.

The KNP which forms part of the Eastern Transvaal Lowveld, is a semi-arid region of the southern temperate zone. Within the Park annual rainfall varies considerably from place to place and even within an area, from one year to the next. Over $80 \%$ of the rain, however, falls during the summer months (October to March) with a concomitant increase in green vegetation. The portion of the Central District from which reproductive data were collected, i.e., the TshokwaneSatara area receives a mean annual precipitation of $529 \mathrm{~mm}(\mathrm{n}=32$ consecutive years, 1941 to 1972) with a range of 232 to 942 millimetres. Mean monthly precipition as registered at these two stations during the study period, are shown in Fig. 6. Mean monthly daylight hours for the study area are also illustrated. These were computed using data on times of sunrise and sunset at latitude $25^{\circ}$ south and longitude $30^{\circ}$ east of Greenwich as supplied by the South African Astronomical Observatory. Average daily temperatures for Skukuza, which is situated on the southern edge of the study area, were calculated from maximum and minimum daily temperatures. By averaging the monthly data for 1969 to 1972, the temperature curves illustrated in Fig. 6 were plotted.

To obtain quantitative data on seasonal mating and foaling activity and also the annual spread of these activities, two basic methods were employed. Firstly the foaling season for the Central District was delimited by doing counts to determine the percentage of newly-born foals surviving to be counted each month. These results are summarised in Tables 4, and 5 and Fig. 6. All these data represent the average condition for the Satara and Eastern Boundary sub-populations and for all practical purposes the condition for the entire Central District.

The second method used to delimit the mating and foaling season was based on a sample of 180 embryos and foetuses collected from shot mares. By measuring the mass of these embryos and foetuses and employing the foetal growth formula of Huggett and Widdas (1951) (Smuts 1975) it was possible to calculate both the month of conception and the projected month of birth of each embryo or foetus (Table 5). Since the collection of this material was undertaken on a monthly basis and the sample was distributed over a period from May 1969 to November 1972, between three and six foetuses could be collected per month. After calculating both the month and year of birth and conception for each embryo or foetus they were then distributed into the 12-monthly intervals (July to June) and the relative percentage conceived or to be born during each month of each 12-month interval was calculated (Table 5).

In Fig. 6 relative monthly conception percentages as given in Table 5 have been illustrated. These can be compared directly with the illustrated 


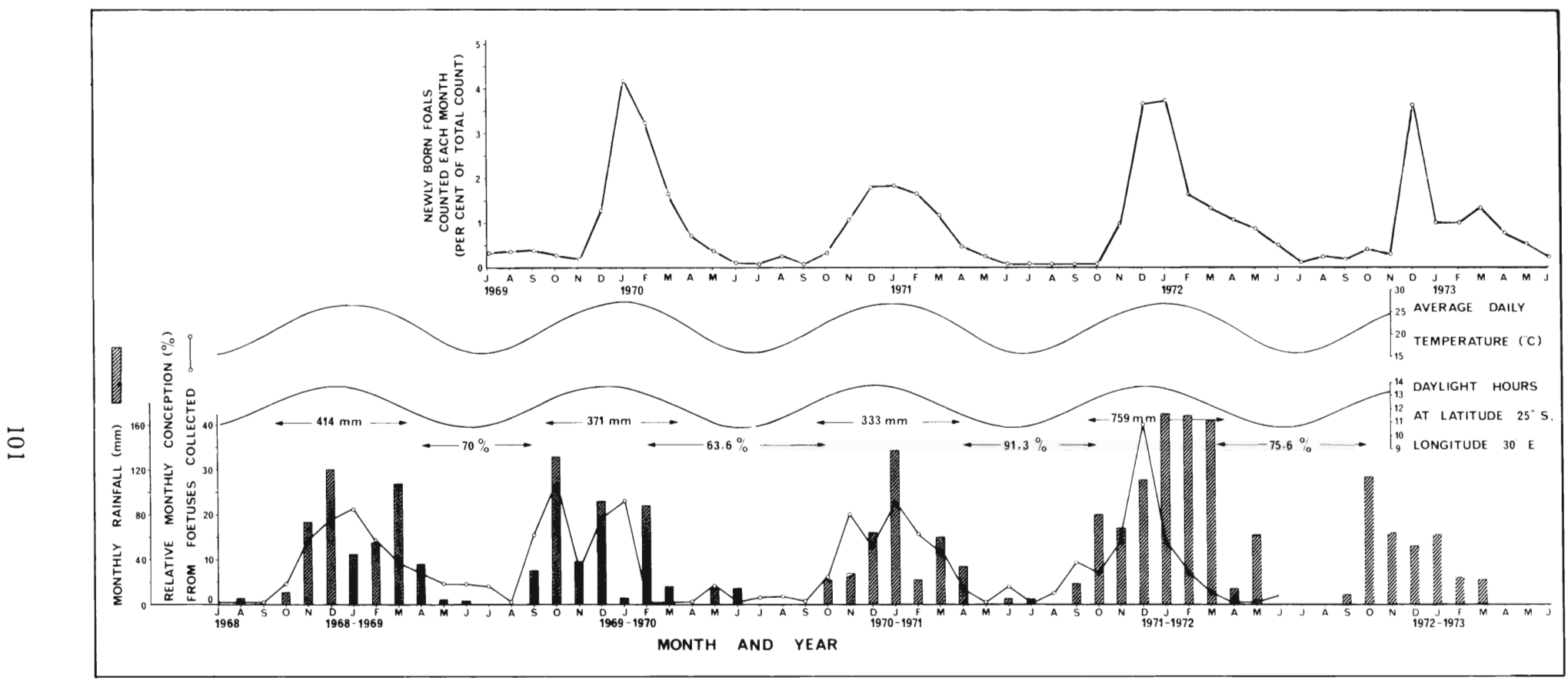

Fig. 6. The foaling season (upper graph) and mating season (lower graph) for zebra from the Central District of the Kruger National Park. Rainfall histograms as well as curves for average monthly daylight hours and average daily temperature are also included in the figure. Total summer precipitation (October to March) and conception rates for mares shot during the winter months of each year are illustrated above and between the conception curves. 
Foaling activity for Burchell's zebra counted at monthly intervals in the Central District of the Kruger National Park between July 1969 and February 1973. Counts have been divided into four 12-monthly intervals so that comparisons can be made between the foaling peaks of successive 12-monthly intervals

\begin{tabular}{|c|c|c|c|c|c|}
\hline $\begin{array}{c}\text { Month } \\
\text { and } \\
\text { Year }\end{array}$ & $\begin{array}{l}\text { Percentage } \\
\text { of newly- } \\
\text { born foals } \\
\text { in each } \\
\text { monthly } \\
\text { sample }\end{array}$ & $\begin{array}{l}\text { Relative } \\
\text { percentage } \\
\text { of newly- } \\
\text { born foals } \\
\text { counted } \\
\text { during } \\
\text { each month }\end{array}$ & $\begin{array}{c}\text { Month } \\
\text { and } \\
\text { Year }\end{array}$ & $\begin{array}{l}\text { Percentage } \\
\text { of newly- } \\
\text { born foals } \\
\text { in each } \\
\text { monthly } \\
\text { sample }\end{array}$ & $\begin{array}{c}\text { Relative } \\
\text { percentage } \\
\text { of newly- } \\
\text { born foals } \\
\text { counted } \\
\text { during } \\
\text { each month }\end{array}$ \\
\hline Julv 1969 & 0,34 & 2,59 & July 1970 & 0,15 & 1,66 \\
\hline Aug. & 0,35 & 2,67 & Aug. & 0,24 & 2,66 \\
\hline Sept. & 0,39 & 2,97 & Sept. & 0,05 & 0,55 \\
\hline Oct. & 0,29 & 2,21 & Oct. & 0,31 & 3,43 \\
\hline Nov. & 0,19 & 1,45 & Nov. & 1,02 & 11,30 \\
\hline Dec. & 1,29 & 9,83 & Dec. & 1,80 & 19,93 \\
\hline Jan. 1970 & 4,18 & 31,86 & Jan. 1971 & 1,83 & 20,27 \\
\hline Feb. & 3,24 & 24,70 & Feb. & 1,66 & 18,38 \\
\hline Mar. & 1,65 & 12,58 & Mar. & 1,15 & 12,74 \\
\hline Apr. & 0,70 & 5,34 & Apr. & 0,46 & 5,09 \\
\hline May & 0,39 & 2,97 & May & 0,27 & 2,99 \\
\hline June & 0,11 & 0,84 & June & 0,09 & 1,00 \\
\hline July 1971 & 0,09 & 0,65 & July $1972^{*}$ & 0,19 & 1,98 \\
\hline Aug. & 0,00 & 0,00 & Aug. & 0,20 & 2,08 \\
\hline Sept. & 0,00 & 0,00 & Sept. & 0,15 & 1,56 \\
\hline Oct. & 0,05 & 0,36 & Oct. & 0,38 & 3,95 \\
\hline Nov. & 0,97 & 7,03 & Nov. & 0,26 & 2,71 \\
\hline Dec. & 3,67 & 26,61 & Dec. & 3,62 & 37,67 \\
\hline Jan. 1972 & 3,72 & 26,98 & Jan. 1973 & 0,98 & 10,20 \\
\hline Feb. & 1,62 & 11,68 & Feb. & 1,00 & 10,41 \\
\hline Mar. & 1,31 & 9,50 & Mar. & 1,37 & 14,26 \\
\hline Apr. & 1,05 & 7,61 & Apr. & 0,74 & 7,70 \\
\hline May & 0,82 & 5,95 & May & 0,49 & 5,10 \\
\hline June & 0,50 & 3,62 & June & 0,23 & 2,39 \\
\hline
\end{tabular}

" During these seven months no counts were undertaken and their results were estimated by averaging the data from the corresponding months of the preceding three years.

climatic variables. Average foaling and mating activity are given in Table 6 which also indicates that the two methods of determining the foaling season provide similar results.

Further evidence for strong seasonal reproductive activity is supplied by analysis of ovaries from 48 non-pregnant adult mares. Of this group 17 were definitely in anoestrus, the rest having either large corpora lutea and/or many developing follicles. Of the 17, one was shot during December and the other 16 between April and July ( 5 in June). This means that over $94 \%$ of all anoestrous mares were collected during the winter (non-breeding season) and indicates that should a mare fail to 
Table 5

Seasonal distribution of births (i) and conceptions (ii) for Burchell's zebra collected in the Central District of the Kruger National Park between May 1969 and November 1972. ( $n=180$ embryos and foetuses)

\begin{tabular}{|c|c|c|c|c|c|c|c|c|c|c|c|c|}
\hline & $\begin{array}{l}\text { Month } \\
\text { and } \\
\text { year of } \\
\text { birth }\end{array}$ & $n^{*}$ & $\begin{array}{c}\text { Relative } \\
\text { percentage } \\
\text { of foals to } \\
\text { be born } \\
\text { during each } \\
\text { month }\end{array}$ & $\begin{array}{l}\text { Month } \\
\text { and } \\
\text { year of } \\
\text { birth }\end{array}$ & $\mathrm{n}$ & $\begin{array}{c}\text { Relative } \\
\text { percentage } \\
\text { of foals to } \\
\text { be born } \\
\text { during each } \\
\text { month }\end{array}$ & $\begin{array}{l}\text { Month } \\
\text { and } \\
\text { year of } \\
\text { birth }\end{array}$ & $\mathrm{n}$ & $\begin{array}{l}\text { Relative } \\
\text { percentage } \\
\text { of foals to } \\
\text { be born } \\
\text { during each } \\
\text { month }\end{array}$ & $\begin{array}{l}\text { Month } \\
\text { and } \\
\text { year of } \\
\text { birth }\end{array}$ & $\mathrm{n}$ & $\begin{array}{c}\text { Relative } \\
\text { percentage } \\
\text { of foals to } \\
\text { be born } \\
\text { during each } \\
\text { month }\end{array}$ \\
\hline \multirow{5}{*}{$\begin{array}{l}z \\
0 \\
\infty \\
\infty \\
\text { s }\end{array}$} & July 1969 & 0 & 0 & July 1970 & 1 & 3,85 & July 1971 & 0 & 0 & July 1972 & 1 & 2,27 \\
\hline & Aug. & 0 & 0 & Aug. & 0 & 0 & Aug. & 2 & 2,94 & Aug. & 1 & 2,27 \\
\hline & Sept. & 0 & 0 & Sept. & 2 & 7,69 & Sept. & 0 & 0 & Sept. & 1 & 2,27 \\
\hline & Oct. & 1 & 2,38 & Oct. & 8 & 30,77 & Oct. & 0 & 0 & Oct. & 3 & 6,82 \\
\hline & Nov. & 3 & 7,14 & Nov. & 3 & 11,54 & Nov. & 11 & 16,18 & Nov. & 7 & 15,91 \\
\hline \multirow{5}{*}{ 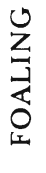 } & Dec. & 10 & 23,81 & Dec. & 3 & 11,54 & Dec. & 12 & 17,65 & Dec. & 17 & 38,64 \\
\hline & Jan. 1970 & 8 & 19,05 & Jan. 1971 & 7 & 26,92 & Jan. 1972 & 13 & 19,12 & Jan. 1973 & 7 & 15,91 \\
\hline & Feb. & 8 & 19,05 & Feb. & 1 & 3,85 & Feb. & 13 & 19,12 & Feb. & 5 & 11,36 \\
\hline & Mar. & 6 & 14,29 & Mar. & 0 & 0 & Mar. & 11 & 16,18 & Mar. & 1 & 2,27 \\
\hline & April & 2 & 4,76 & April & 0 & 0 & April & 3 & 4,41 & April & 0 & 0 \\
\hline \multirow[t]{2}{*}{$\Xi$} & May & 0 & 0 & May & 1 & 3,85 & May & 1 & 1,47 & May & 0 & 0 \\
\hline & June & 4 & 9,52 & June & 0 & 0 & June & 2 & 2,94 & June & 1 & 2,27 \\
\hline
\end{tabular}


Table 5. (Continued)

\begin{tabular}{|c|c|c|c|c|c|c|c|c|c|c|c|c|}
\hline & $\begin{array}{l}\text { Month and } \\
\text { year of } \\
\text { concep- } \\
\text { tion }\end{array}$ & $\mathrm{n}^{*}$ & $\begin{array}{c}\text { Relative } \\
\text { monthly } \\
\text { conception } \\
\text { percentage }\end{array}$ & $\begin{array}{l}\text { Month and } \\
\text { year of } \\
\text { concep- } \\
\text { tion }\end{array}$ & $\mathrm{n}$ & $\begin{array}{c}\text { Relative } \\
\text { monthly } \\
\text { conception } \\
\text { percentage }\end{array}$ & $\begin{array}{l}\text { Month and } \\
\text { year of } \\
\text { concep- } \\
\text { tion }\end{array}$ & $\mathrm{n}$ & $\begin{array}{c}\text { Relative } \\
\text { monthly } \\
\text { conception } \\
\text { percentage }\end{array}$ & $\begin{array}{l}\text { Month and } \\
\text { year of } \\
\text { concep- } \\
\text { tion }\end{array}$ & $\mathrm{n}$ & $\begin{array}{c}\text { Relative } \\
\text { monthly } \\
\text { conception } \\
\text { percentage }\end{array}$ \\
\hline \multirow{12}{*}{$\begin{array}{l}2 \\
y \\
\\
\end{array}$} & July 1968 & 0 & 0 & July 1969 & 1 & 3,85 & July 1970 & 1 & 1,43 & July 1971 & 0 & 0 \\
\hline & Aug. & 0 & 0 & Aug. & 0 & 0 & Aug. & 1 & 1,43 & Aug. & 1 & 2,38 \\
\hline & Sept. & 0 & 0 & Sept. & 4 & 15,38 & Sept. & 0 & 0 & Sept. & 4 & 9,52 \\
\hline & Oct. & 2 & 4,76 & Oct. & 7 & 26,92 & Oct. & 4 & 5,71 & Oct. & 3 & 7,14 \\
\hline & Nov. & 6 & 14,29 & Nov. & 2 & 7,69 & Nov. & 14 & 20,00 & Nov. & 6 & 14,29 \\
\hline & Dec. & 8 & 19,05 & Dec. & 5 & 19,23 & Dec. & 9 & 12,86 & Dec. & 17 & 40,48 \\
\hline & Jan. 1969 & 9 & 21,43 & Jan. 1970 & 6 & 23,08 & Jan. 1971 & 16 & 22,86 & Jan. 1972 & 6 & 14,29 \\
\hline & Feb. & 6 & 14,29 & Feb. & 0 & 0 & Feb. & 11 & 15,71 & Feb. & 3 & 7,14 \\
\hline & Mar. & 4 & 9,52 & Mar. & 0 & 0 & Mar. & 9 & 12,86 & Mar. & 1 & 2,38 \\
\hline & April & 3 & 7,14 & April & 0 & 0 & April & 2 & 2,86 & April & 0 & 0 \\
\hline & May & 2 & 4,76 & May & 1 & 3,85 & May & 0 & 0 & May & 0 & 0 \\
\hline & June & 2 & 4,76 & June & 0 & 0 & June & 3 & 4,29 & June & 1 & 2,38 \\
\hline
\end{tabular}

$* \mathrm{n}=$ the number of embryos and foetuses used to calculate the relative percentages. 
Table 6

Average foaling and mating activity for Burchell's zebra in the Central District of the Kruger National Park for the years 1969 to 1973. This table represents the averages for the data given in Tables 4 and 5

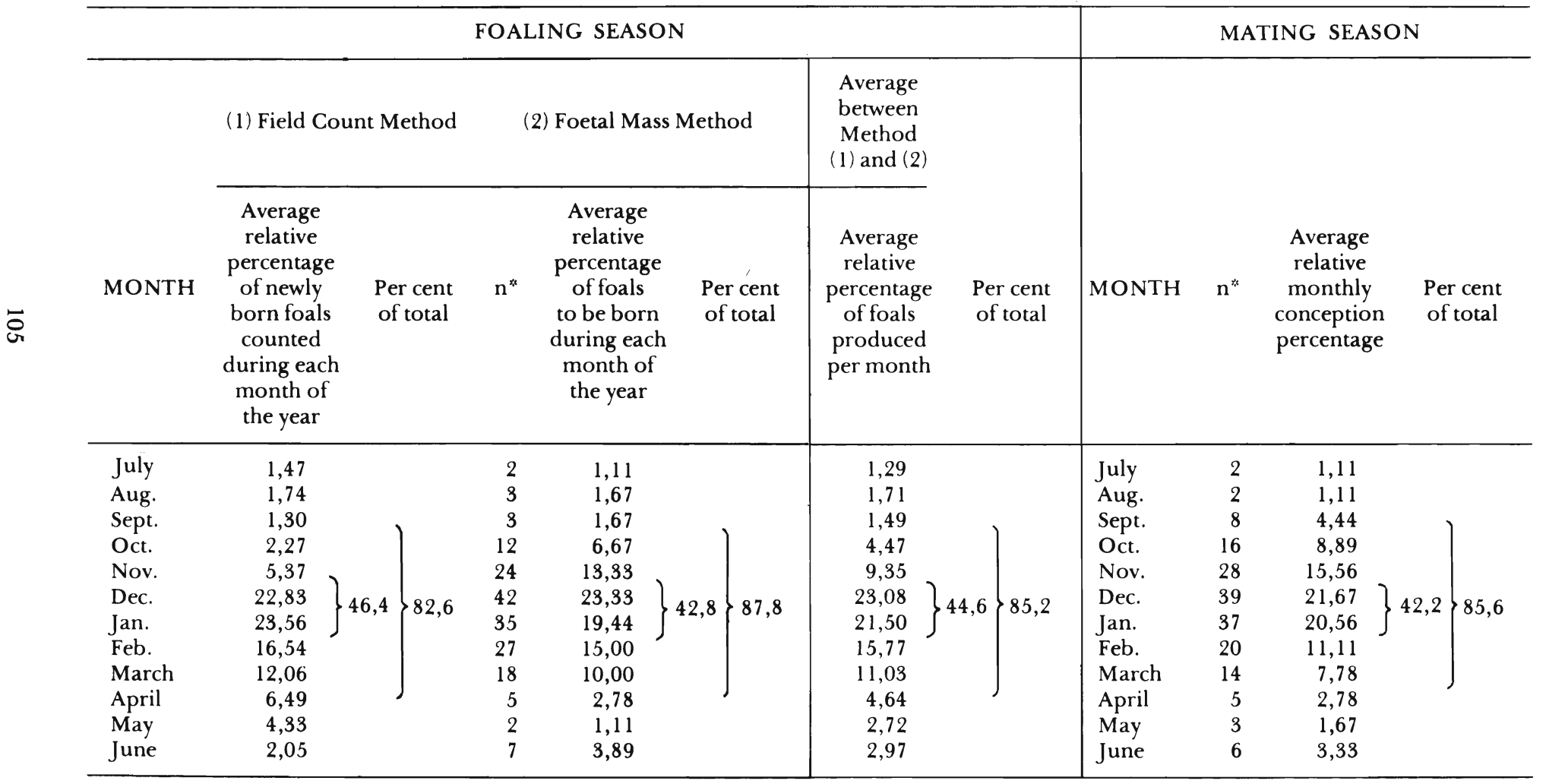

" $\mathrm{n}=$ the number of embryos and foetuses used to calculate the relative percentages 
conceive during the summer, she is likely to remain in anoestrus during the ensuing winter. Analysis of these ovaries is discussed in a later section.

\section{Conception rate and the factors affecting it}

Between 1969.05.16 and 1972.11.13 the reproductive tracts of 236 adult ( 3 to 20 -year old) mares were examined to ascertain their reproductive status. Of this sample, 184 were confirmed pregnant (78\%) as indicated by the presence of a conceptus in the uterus. In addition to these, 35 adult mares were shot by various staff members during 1966 . Of this sample 31 were visibly pregnant $(88,6 \%)$. The conception rate for the entire sample of 271 adult mares of which 215 were visibly pregnant, is $79,3 \%$ and covers a period of five years. Breakdown of conception data into the various adult age classes is given in Table 7.

Table 7

Age-specific conception rates for 279 Burchell's zebra mares collected in the Central District of the Kruger National Park between 1969 and 1972

\begin{tabular}{cccc}
\hline $\begin{array}{c}\text { AGE CLASS } \\
\text { (YEARS) }\end{array}$ & $\mathrm{n}$ & $\begin{array}{c}\text { NO. VISIBLY } \\
\text { PREGNANT }\end{array}$ & $\begin{array}{c}\text { CONCEPTION } \\
\text { RATE (\%) }\end{array}$ \\
\hline $1-2$ & 19 & 1 & $5,3^{*}$ \\
$2-3$ & 24 & 6 & 25,0 \\
$3-4$ & 15 & 11 & 73,3 \\
$4-5$ & 21 & 19 & 90,5 \\
$5-6$ & 30 & 20 & 66,7 \\
$6-7$ & 22 & 16 & 72,7 \\
$7-8$ & 26 & 18 & 69,2 \\
$8-9$ & 14 & 12 & 85,7 \\
$9-10$ & 22 & 15 & 68,2 \\
$10-11$ & 18 & 15 & 83,3 \\
$11-12$ & 27 & 25 & 92,6 \\
$12-13$ & 14 & 14 & 100,0 \\
$13-14$ & 7 & 5 & 71,4 \\
$14-15$ & 10 & 9 & 90,0 \\
$15-16$ & 8 & 4 & 50,0 \\
$16-17$ & 0 & - & - \\
$17-18$ & 2 & 2 & 100,0 \\
\hline
\end{tabular}

* The single pregnant mare in this group was in the process of aborting when shot 
By dividing the collection of adult mares from the Central District into two groups representing those from the sedentary Satara subpopulation and those from the migratory Eastern Boundary sub-population, the following conception rates were obtained:

Satara sub-population: $80,2 \%(\mathrm{n}=111$ mares)

Eastern boundary sub-population: 78,8\% ( $\mathrm{n}=160$ mares). These differences are not significant at the $5 \%$ level (Chi-square $=0,01$ ).

Since conception rate is relatively constant throughout the Central District it would be interesting to determine whether rates differ significantly from one year to the next. However, to compare the conception rate of one breeding season with that of another it is necessary, in the case of the zebra, to separate the sample of adult mares into those collected during the breeding (mating) season and those collected during the non-breeding season. This is essential because only those collected during the non-breeding seasons of individual years can be compared. The reason is that mares shot during the mating season and carrying large foetuses are mares that have reacted to conditions from the previous season, while those carrying small foetusses or embryos have fallen pregnant during the current season and therefore reflect the conditions of this season. Conception data collected during both these times of the year would thus represent the average condition for two successive breeding seasons and it would subsequently be difficult to assess the effects of a particular season on conception rate. The same would apply to non-pregnant mares, i.e. one would not know which season was responsible for their condition.

Bearing the above-mentioned in mind and looking at the graph of relative monthly conception percentages illustrated in Fig. 6, it is possible to divide the period of collection into non-mating seasons as given in Table 8. These seasons represent intervals of time which start when monthly conception percentage drops drastically and extend up to the time when monthly conception percentage shows its first marked in-

Table 8

Comparison of non-breeding season conception rates for Burchell's zebra for each of four consecutive years. Only adult mares ( 3 to 20 years old) collected in the Central District of the Kruger Park were used

\begin{tabular}{lcccc}
\hline $\begin{array}{l}\text { Non-breeding Season } \\
\text { (Non-mating Season) }\end{array}$ & $\begin{array}{c}\text { Approximate } \\
\text { length of } \\
\text { Season } \\
\text { (Months) }\end{array}$ & $\begin{array}{c}\text { No. of } \\
\text { Adult } \\
\text { Mares } \\
\text { shot }\end{array}$ & $\begin{array}{c}\text { No. } \\
\text { confirmed } \\
\text { Pregnant }\end{array}$ & $\begin{array}{c}\text { Conception } \\
\text { Rate(\%) }\end{array}$ \\
\hline April '69-Sept.' '69 & 5 & 20 & 14 & 70,0 \\
Feb. '70-Oct.'70 & 8 & 44 & 28 & 63,6 \\
April'71-Oct. '71 & 6 & 46 & 42 & 91,3 \\
March'72-Oct.' '72 & 7 & 41 & 31 & 75,6 \\
\hline
\end{tabular}


crease. Mares collected during these periods would, in the majority of cases, have reacted to the conditions of the preceding summer season and their conception rate would thus be representative of that season. Conception rates for the four non-breeding seasons experienced during the study period are also given in Table 8 and in Fig. 6 .

\section{Ovarian activity during the oestrous cycle}

For convenience the ovarian cycle of the adult mare has been divided into two sections, namely ovarian activity during the oestrous cycle and ovarian activity during pregnancy. These cycles, however, follow each other should fertilization and implantation be effected.

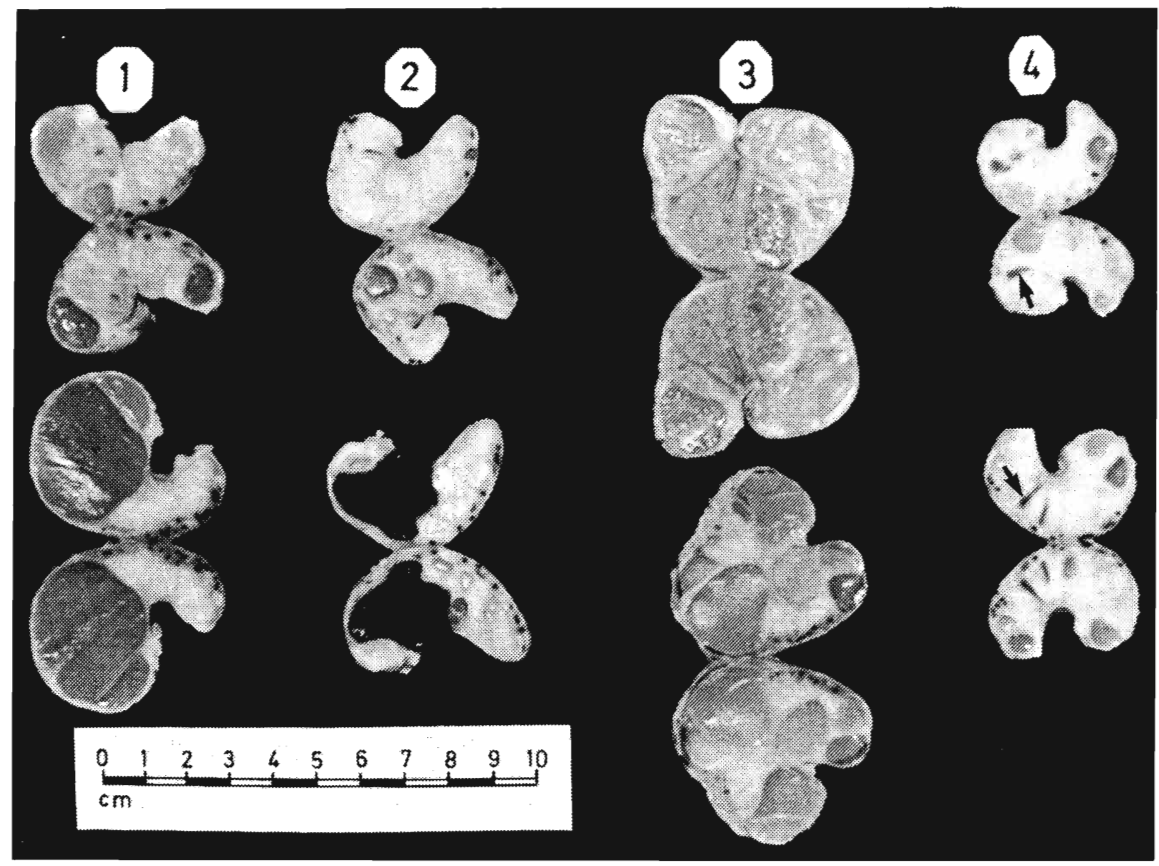

Fig. 7. Four pairs of Burchell's zebra ovaries cut from their free to attached b.orders and opened out to illustrate their internal appearance at four phases of the oestrous cycle. (1) Pro-oestrus - one follicle in the lower ovary has increased in size, while the upper ovary contains two corpora lutea from previous oestrous cycles; (2) Metoestrus - note the large corpus haemorrhagicum and the absence of large and medium-sized follicles; (3) Dioestrus - the corpus luteum has started to regress and follicular development is apparent. This is probably a late dioestrus specimen and most of the ovarian stroma is taken up with follicles of various sizes; (4) Anoestrus - the typical anoestrus ovary assumes a cashew nut shape and lacks medium-sized and large follicles. Dark brown corpora lutea in the final stages of regression (see arrows) are frequently present while stroma is very obvious. Notice that in all specimens ovulation has taken place via the ovarian fossa. 
The phases of the oestrous cycle in the zebra have been outlined in a previous section. These phases are, however, primarily related to the activity of the ovaries and in this context they may be summarised as follows:

Pro-oestrus - there is a marked increase in follicular activity with one follicle generally considerably larger than the others. Regressing corpora lutea from preceding cycles may be present (Fig. 7).

Oestrus - similar to pro-oestrus except that there is no doubt as to which follicle is going to rupture and the mare now accepts the stallion. Unfortunately none of the cropped mares could be placed in this category.

Table 9

Characteristics of the ovaries of 42 adult, non-pregnant Burchell's zebra mares shot in the Central District of the Kruger National Park

\begin{tabular}{|c|c|c|c|c|c|}
\hline Feature of $\mathrm{Ov}$ & & Pro-oestrus & Metoestrus & Dioestrus & Anoestrus \\
\hline & Mean & 25,1 & 16,0 & 18,0 & 9,9 \\
\hline Mass (g) & Max. & 36,8 & 30,0 & 39,8 & 18,1 \\
\hline & Min. & 15,8 & 6,0 & 5,4 & 4,8 \\
\hline & Mean & 4,4 & 4,3 & 4,0 & 3,5 \\
\hline Length $(\mathrm{cm})$ & Max. & 4,7 & 5,5 & 6,0 & 4,6 \\
\hline & Min. & 3,8 & 3,5 & 2,7 & 2,8 \\
\hline & Mean & 3,0 & 2,2 & 2,6 & 2,1 \\
\hline Width $(\mathrm{cm})$ & Max. & 4,2 & 2,8 & 3,2 & 2,8 \\
\hline & Min. & 2,2 & 1,6 & 1,2 & 1,5 \\
\hline & $\begin{array}{l}\text { Diameter } \\
\quad(\mathrm{mm})\end{array}$ & & & & \\
\hline Range in number & $1-10$ & $10-57$ & $10-44$ & $6-41$ & $11-41$ \\
\hline of follicles per pair & $11-20$ & $2-9$ & $0-3$ & $1-17$ & $0-2$ \\
\hline of ovaries & $21-30$ & $0-1$ & 0 & $0-2$ & 0 \\
\hline & $31-40$ & $0-1$ & 0 & 0 & 0 \\
\hline Greatest diameter o & llicle (mm) & 31 & 20 & 25 & 13 \\
\hline & $\begin{array}{l}\text { Diameter } \\
(\mathrm{mm})\end{array}$ & & & & \\
\hline Range in number & $1-10$ & $1-6$ & $0-1$ & $0-4$ & $0-6$ \\
\hline of corpora lutea & $11-20$ & $0-2$ & $0-1$ & $0-1$ & 0 \\
\hline per pair of ovaries & $21-30$ & 0 & $0-1$ & $0-1$ & 0 \\
\hline & $31-40$ & 0 & $0-1$ & 0 & 0 \\
\hline $\begin{array}{l}\text { Greatest diameter o } \\
(\mathrm{mm})\end{array}$ & pus luteum & 20 & 32 & 27 & 10 \\
\hline
\end{tabular}


Metoestrus - the ripe graafian follicle has ruptured and a characteristic corpus haemorrhagicum formed. At this stage the cavity of the follicle is filled with a lymph-like fluid which usually has a considerable amount of extravasated blood in it (Fig. 7). As the cells lining the ruptured follicle undergo rapid hypertrophy and become luteinized, an orange coloured corpus luteum is formed. Follicular activity is largely in abeyance.

Dioestrus - should the mare fail to conceive, she goes into dioestrus or anoestrus. During dioestrus graafian follicles start developing slowly (Fig. 7) while the corpus luteum starts to regress, becoming smaller and lighter (yellow) in colour. This phase is generally followed by the prooestrus phase.

Anoestrus - mares which have failed to conceive towards the end of the mating season may cease to cycle and go into anoestrus. The ovaries of anoestrous mares (Fig. 7) are relatively inactive and contain a few small follicles and usually a number of tiny dark brown corpora lutea in advanced stages of regression (corpora albicantia).

Changes occurring in the ovaries of 42 adult non-pregnant mares are given in Table 9 and should be compared with Fig. 7 which illustrates examples of four of the phases of the oestrous cycle.

In the sample of 42 adult non-pregnant mares, there was only one specimen in which a multiple (double) ovulation may have taken place. This was a pro-oestrous mare with a regressing corpus luteum in each ovary. These corpora lutea measured $19 \times 19$ and $20 \times 19$ millimetres.

The sample of 42 was a bit small to satisfactorily gauge comparative ovarian activity but in $64 \%$ of the specimens the left ovary had a greater mass than the right, while in $60 \%$ the corpus luteum was situated in the left ovary. The sample sizes precluded statistical evaluation.

In none of the ovaries sectioned was there any evidence that ovulation had taken place from any region of the ovary other than the ovarian fossa. In a number of cases there was protrusion of the corpus luteum or corpus haemorrhagicum (Fig. 7) from the ovarian fossa.

\section{Ovarian activity during pregnancy}

Ovarian activity during the 375-day long gestation period of the zebra mare has been divided into 19 arbitrary phases (Table 10). Unfortunately there were only four specimens available for mares in the early stages of pregnancy (phases 1 to 3 ), this largely being due to the fact that mares are easily classified non-pregnant during the first week or two after conceiving and that hunters were reluctant to shoot mares with young foals at foot. For the other 16 phases, each of which (except the last one) covers a period of 20 days, larger samples were available. Altogether 172 pairs of ovaries from pregnant mares were sectioned, the more important data being summarised in Table 10. Representative pairs of 
Data collected from macroscopical sections made on 172 pairs of ovaries from Burchell's zebra at various stages of pregnancy. Data have been grouped into 19 arbitrary pregnancy phases and means, maxima and minima for various parameters of each phase calculated. All mares were shot in the Central District of the Kruger National Park between 1969 and 1972

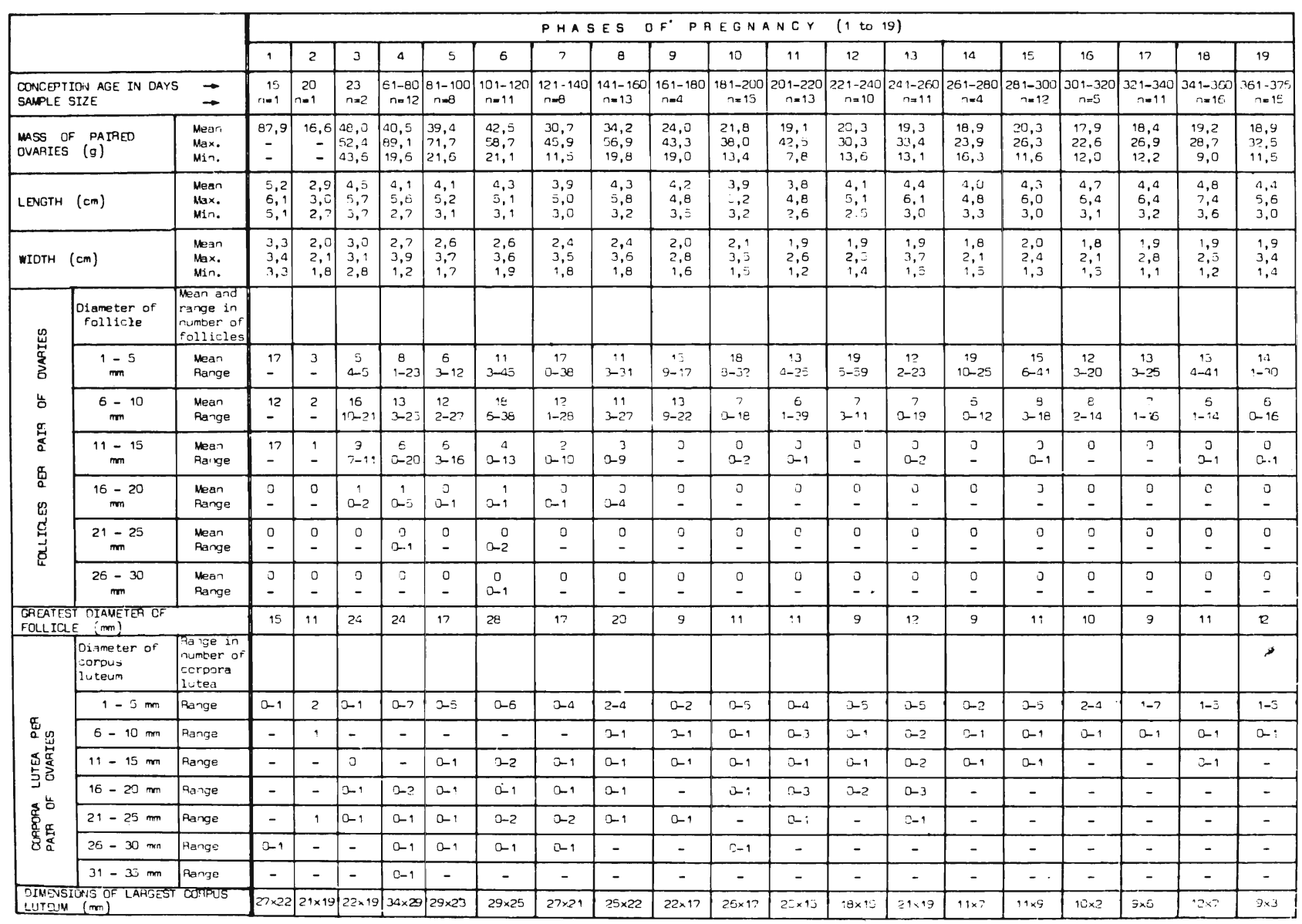


ovaries from mares at various stages of pregnancy appear in Fig. 8. The ovaries of zebra mares present a number of interesting features. Firstly follicular development is stimulated during certain phases of pregnancy

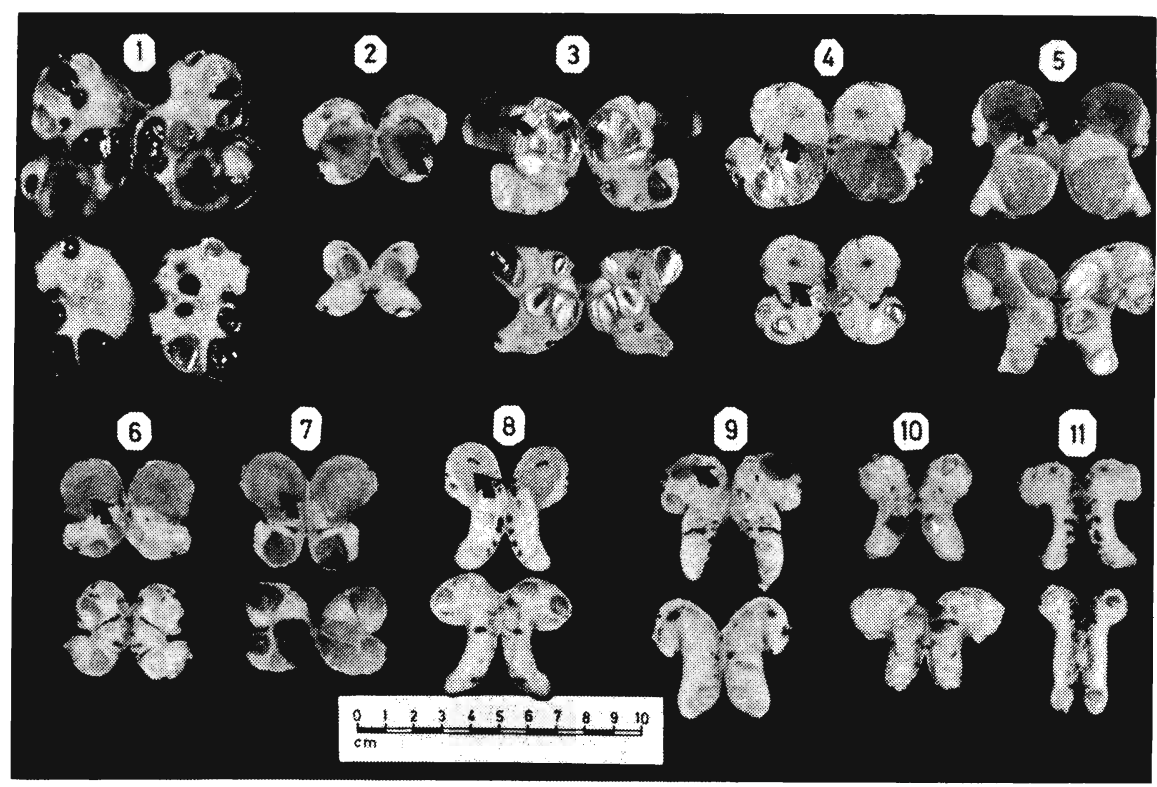

Fig. 8. Eleven pairs of ovaries from Burchell's zebra mares at various stages of pregnancy. The ovaries have been cut from their free to attached borders and opened out to illustrate the internal appearance. All ovarian pairs are arranged vertically with the tubal extremity uppermost. On the photograph the coagulated liquor folliculi of most follicles appears as a shiny surface, while the corpora lutea are duller, one half of each being pin-pointed by a small black arrow. Legend: (1) $=15$ days pregnant. Notice many small follicles and the large developing corpus luteum with blood stained liquor folliculi still in the centre. (2) $=20$ days pregnant. At this stage the corpus luteum of pregnancy has already reached its maximum size and there was a reduction in follicular activity; $(3)=74$ days. At this stage there was an increase in follicular activity while the corpus luteum of pregnancy was gradually regressing; $(4)=102$ days. In this specimen as in (5), follicular activity is still obvious. It also has two corpora lutea both being approximately the same size; $(5)=113$ days; $(6)=135$ days. This specimen shows reduced follicular activity in both ovaries, while a luteal scar (corpus albicans) is clearly visible as a dark narrow streak in the lower ovary. This is a structure from a previous oestrous cycle; $(7)=145$ days. Here ovarian activity is still obvious in both ovaries; $(8)=165$ days. In this specimen follicular activity is reduced, as is the size of the corpus luteum of pregnancy; $(9)=239$ days. Strongly reduced follicular activity and a small corpus luteum and one corpus albicans; $(10)=343$ days. Little follicular activity and no visible corpora lutea; $(11)=375$ days of full-term. Two small follicles are visible in the lower ovary. Both ovaries have become long and thin - a typical shape for the late stages of pregnancy. 
and secondly, this activity may be followed by ovulation resulting in the formation of so called secondary corpora lutea.

Using average data in Table 10 together with raw data on individual pairs of ovaries, Figs. 9 and 10 have been prepared. These figures illustrate ovarian activity during pregnancy and use the mass and width of the gland respectively, as indices of activity.

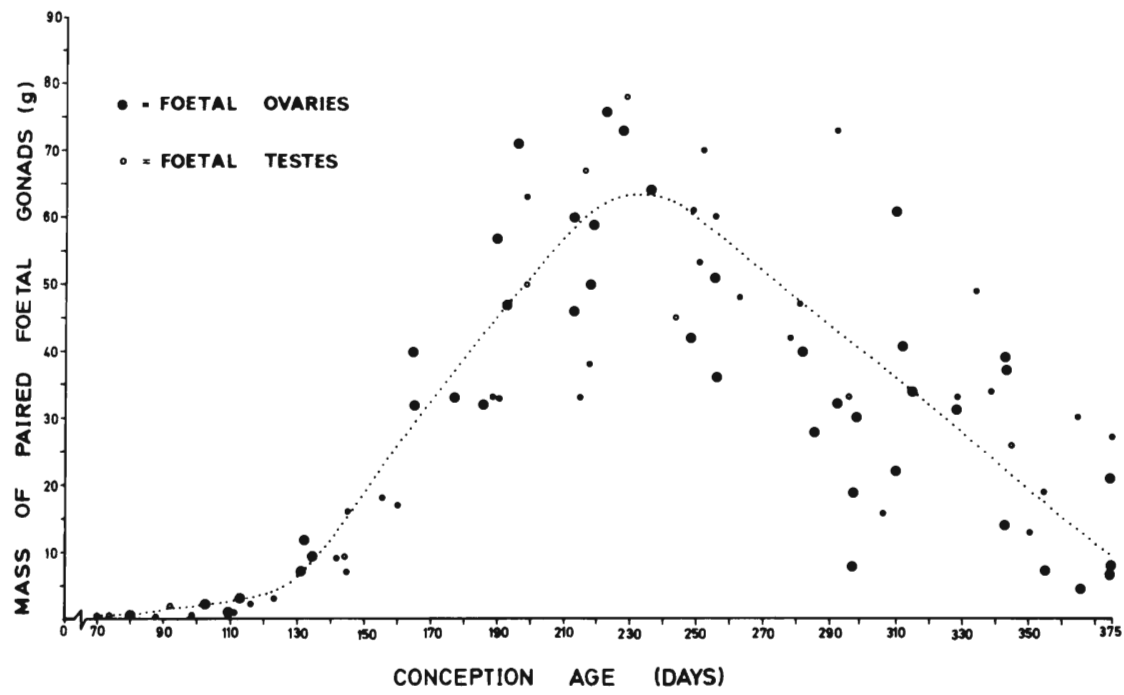

Fig. 9. Scatter diagram illustrating changes in the mass of paired Burchell's zebra ovaries during pregnancy. Average results for the 19 arbitrary phases of pregnancy given in Table 10 are also illustrated (closed circles). The curve was fitted by eye.

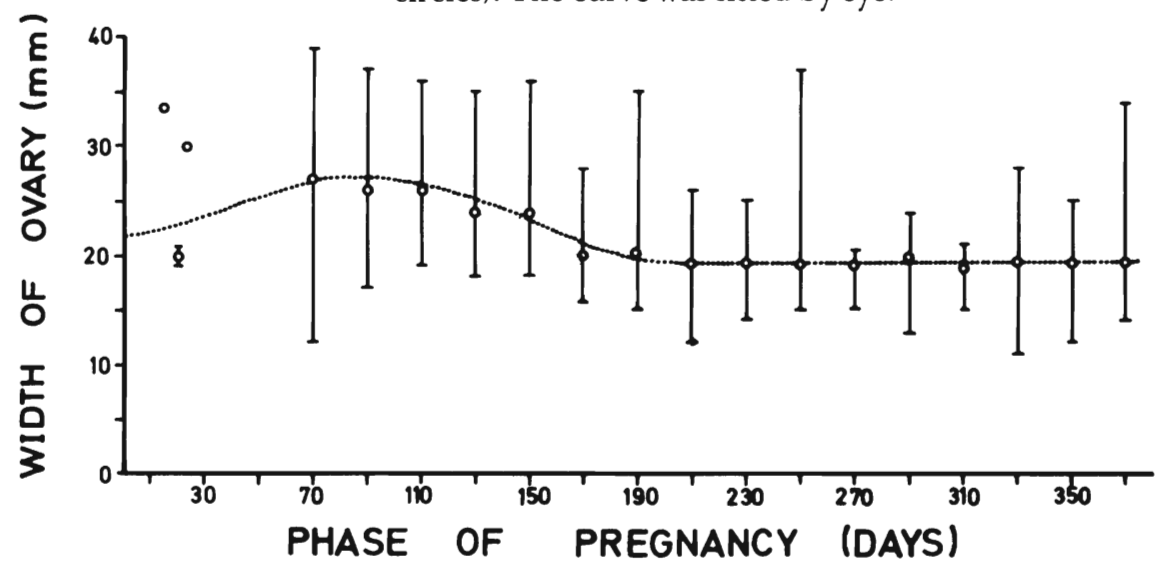

Fig. 10. Width of Burchell's zebra ovaries (smooth surface to smooth surface) as an index of follicular activity. The open circles give the average width for each of the 19 arbitrary phases of pregnancy given in Table 10 and the vertical lines the total variation of each. The curve was fitted by eye. 
In addition to the above-mentioned indirect methods of assessing ovarian activity, activity can be gauged directly from the size of developing or regressing follicles. Follicles with the greatest diameter are found between a conception age of 23 and 160 days (Table 10). In one instance of a mare, estimated 102 days pregnant, there was a graafian follicle with a diameter of 28 millimetres. This follicle may be compared to prooestrous follicles (Table 9). In addition the only two instances of recent ovulations (corpora haemorrhagica) during pregnancy were found in mares 72 and 98 days pregnant. Since good samples were available for the rest of pregnancy, it is obvious that follicular activity reaches a maximum between about 70 and 110 days and that secondary corpora lutea resulting from ovulation may be found during these stages. After this stage of increased follicular development there is a gradual regression of follicles until the relatively inactive 190 to 375 day stage is achieved.

In contrast to follicular activity, the corpus luteum of pregnancy shows less spectacular changes. In mares with single ovulations and no secondary corpora lutea, the corpus luteum of pregnancy regresses fairly slowly and remains clearly visible in most full and near-term mares. Here it appears as a dark yellow-brown corpus albicans with dimensions of up to $10 \times 2$ millimetres. In mares with secondary corpora lutea, it is impossible to gauge what happens to the corpus luteum of pregnancy but it is likely that it regresses more rapidly than in mares without secondary corpora lutea. In mares with more than one corpus luteum, the largest may still measure $21 \times 19 \mathrm{~mm}$ at 249 days (Table 10). In Fig. 8 the upper ovary of the number " 9 " pair shows a fairly large regressing corpus luteum. This animal was 239 days pregnant. Figure 8 also illustrates the gradual regression in size of the corpus luteum of pregnancy. No corpora lutea are visible in the last two pairs of ovaries (10 and 11) although sections further down produced the characteristic scar tissue of corpora albicantia.

By counting and measuring corpora lutea in the 172 pairs of ovaries sectioned, it was found that $26(15,1 \%)$ animals had secondary corpora lutea, i.e., two or more corpora lutea which definitely originated during the current pregnancy. As mentioned, two of these were fresh corpora haemorrhagica, the rest being corpora lutea in various stages of regression. All secondary corpora lutea appeared to have resulted from ovulations - in contrast to the possibility that luteinization of an unrupted follicle may have occurred. In this respect all corpora lutea had the typical pear shape with the narrow core region abutting on the ovarian fossa (Fig. 8, ovary pairs numbers 3 to 8 ). Of the 26 individuals showing secondary corpora lutea, 23 had one secondary corpus luteum, two had two secondary corpora lutea and one (a mare 249 days pregnant) may have had three or more. In the latter mare a total of eight corpora lutea with diameters of between six and $21 \mathrm{~mm}$ were identified all were produced from follicles which had ovulated. It is, however, unlikely that all the corpora lutea had been produced during the current 
pregnancy, i.e. two or three could possibly have been from oestrous cycles prior to the pregnancy.

The distribution of the 23 single secondary corpora lutea and the corpora lutea of pregnancy were as follows:

One in the left ovary and one in the right ovary $=13$

Both in the left ovary $=7$

Both in the right ovary $=3$

In the three pairs of ovaries with two or more secondary corpora lutea, the left ovary again showed the greater activity.

With regard to differential activity of the ovaries, a number of deductions can be made. As in the case of the stallion (Smuts 1976), the left gland of the mare appears to be more active than the right. Excluding the tiny corpora albicantia ( 1 to $5 \mathrm{~mm}$ diameter) which are easily missed when sectioning ovaries macroscopically, a total of 109 corpora lutea were counted in all left ovaries and 73 in all right ovaries. This disparity (60\% left and $40 \%$ right) indicates a differential ovulation rate and is a highly significant deviation from the expectation that ovaries are equally active (Chi-square $=7,12 ; p<0,01$ ). Where the corpora lutea of pregnancy could be positively identified, 32 were in the left and 16 in the right ovary. Similarly the mass of the left and right ovaries differed significantly from one another. Out of 340 ovaries (170 pairs) the left ovary had a greater mass than the right in 120 instances $(70,6 \%$ left $>$ right) (Chi-square $=28,82 ; p<0,005)$.

Since the left ovary is more active than the right, it would be interesting to see how this compares with implantation. In a sample of 63 pregnant mares in which the side of implantation was ascertained without any doubt, $35(55,6 \%)$ were left and $28(44,4 \%)$ right. However, in 48 of these 63 , the corpus luteum of pregnancy could also be identified and it was found that trans-uterine migration had occurred in 20 instances $(41,7 \%)$. In the other 28 cases ovulation and implantation occurred on the same side. Of the 20 migrations 12 were from the left horn of the uterus to the right.

\section{Ovarian abnormalities}

During the present study 262 pairs of ovaries from mares between one and 18 years of age were examined and macroscopically sectioned. Of this sample, 219 pairs were from adult mares (over 3 years of age). Gross examination of these ovaries indicated that five pairs displayed bi- or unilateral abnormalities, all five being from mares in the adult group. Histological aspects of these ovaries are described in detail by Imes and Smuts (1975).

\section{Discussion}

Short term studies on aspects of reproduction in the zebra mare (E.b. boehmi) have been undertaken by King (1965) in East Africa, while some comparative aspects of reproduction in the Equidae have been discussed 
by King (1966). Other studies on Burchell's zebra have also been undertaken on the subspecies boehmi and here the studies of Klingel merit mention (see Klingel 1965, 1967 and $1969 \mathrm{a}$ and b and Klingel and Klingel 1965) as do those of Trumler (1958) and Wackernagel (1965).

\section{The oestrous cycle}

According to Wackernagel (1965), oestrus in Burchell's zebra lasts from two to nine days (six days in the present study). The first postpartum oestrus which occurred at eight to nine days is in agreement with the nine to 10 days of Wackernagel (1965) and the seven days given by Klingel (1969a). Wackernagel (op cit.) also found the length of the dioestrous period to be between 17 and 24 days (range $=i 1$ to 28 days). These observations are similar to the domestic horse where oestrus varies from five to nine days (Asdell 1946), depending on the breed. In South Africa, foal heats of the horse have been recorded commencing at 8,8 days (du Plessis 1964) and eight to 11 days (Belonje 1949). The average length of the oestrous cycle has been recorded at 23,7 days (van Niekerk 1967) (South Africa) and 22,8 days (Sato and Hoshi 1934) (Korean mares in Japan) while the length of dioestrus was from 11 to 16 days (Day 1940) and 17 to 19 days (Belonje 1949).

\section{Gestation period pregnancy and birth}

As is the case with the various breeds of domestic horse, duration of gestation in zebras is extremely variable. Kenneth and Ritchie (1953), for example, quote periods ranging between 336 and 375 days, for Equus burchelli. More recently Wackernagel (1965) was able to determine the gestation period for 28 Grant's zebra (Equus burchelli boehmi) conceived and born in the Basle Zoo, Switzerland. Here the average for both male and female foals was 371,2 days. Males were carried longer, on an average 373,2 days (range $=361-390$ days) while females were carried on an average for 369,5 days (range $=361$ to 378 days). Comparative results are given by Klingel (1969a), i.e. 378 and 385 days while in the present study it was 398 days.

Aspects of the birth process as it occurs in Burchell's zebra have been described by Klingel and Klingel (1965) and Wackernagel (1965). Wackernagel (op cit.) also measured the mass of two afterbirths $(2,7$ and $2,9 \mathrm{~kg})$ which were similar to those in the present study $(3,2$ and $3,3 \mathrm{~kg})$.

\section{Mother-foal relationships}

The close bond between a mare and her young foal must be of considerable survival value during the critical period of imprinting. Similarly the protective role of the mare must be of value since Klingel and Klingel (1965) have seen it operate in the presence of predators such as spotted hyenas (Crocuta crocuta). Here mares with young foals would hide behind other members of the family group. 


\section{Lactation and weaning}

Although most foals are weaned at 11 months of age they may be separated from their mothers at an earlier age without ill effects. In one instance, for example, a foal had already become a member of a stallion group at nine months of age. This animal had probably lost its mother a short while before. Captive foals forcibly separated from their mothers have been successfully weaned at six to eight months of age, while King (1965) gives the weaning age for E.b. boehmi as seven months.

\section{Development of the uterus and vagina}

As is the case with the stallion (Smuts 1976) the general morphology and location of the female reproductive tract and its associated structures are very similar to those of the domestic horse (Eckstein and Zuckerman 1962) and have been described by King (1965). By comparing the dimensions of the tubular genitalia (Table 1) with the minimum values given for adult mares in Table 2, it can be seen that in most instances the adult dimensions have been attained by 2,5 years of age.

\section{Development of the ovaries}

In Fig. 2 it can be seen that the mass of the foetal gonad increases very slowly up to a conception age of approximately 125 days after which there is a rapid increase in mass until about 230 days. After this age they gradually decrease in size until just after birth when a minimum mass of approximately four grams is attained. The fluctuations are strikingly similar to those reported for foetal horse gonads by Cole, Hart, Lyons and Catchpole (1933) and Amoroso and Rowlands (1951).

The large variation in ovary mass for the different age classes of adults shown in Fig. 3 is mainly due to the reproductive status of each mare. Average data, however, indicates that ovarian growth in young mares is rapid and that the average mass of the active adult ovary is attained at about 20 months of age. This contrasts with the stallion where the minimum mass of adult testes is attained for the first time by 3,5 year old stallions (Smuts 1976). Fig. 4 ((6) to (10)) clearly shows the extent to which growth of the post natal ovary is dependent on follicular and luteal development.

The observation that ovulation in the zebra mare occurs via the ovarian fossa has been verified in studies on the domestic horse. Here Witherspoon and Talbot (1970) found that the fimbria were displaced in a position where they covered the areas of the ovarian fossa alone, but not the entire ovarian surface. Their research involved the use of fiberoptics, cinematography, India ink translocation and histologic evaluation.

\section{Puberty and sexual maturity}

In the present study no direct field observations were made with respect to mating activity in young mares. Wackernagel (1965), however, 
found that young captive zebra mares displayed the first signs of oestrus at 15,5 months while King (1965) gives an age of 22 months. Klingel (1969a) states in his study that the youngest mares that were recorded being served were estimated to be 18 months old. With rapid ovarian development commencing at about 16 months of age (Fig. 3) and since one mare had conceived at 17 months of age and later aborted her foetus, it would seem that the pubertal interval extends from about 16 to 22 months with the first successful conceptions occurring at 23 months. This is supported by ovulations, the first of which were noted in mares 1,5 to two years old. Although mares may conceive successfully at 23 months of age the average age of first conception ( 28 months) indicates that most mares only become fully mature during their third year of life. These conclusions are supported by data given by King (1965) where the average age of first conception was also 28 months (range $=22$ to 33 months). Wackernagel on the other hand obtained ages of 30 and 31 months for captive mares with another of 20 months for a mare which aborted five months later. Klingel (1969a) found that the first successful conceptions occurred at about 30 months of age. In addition to chronological age, body mass is known to be related to puberty (Joubert 1963) and in the zebra mare the body mass range displayed by adult mares is attained for the first time by two-year olds (Smuts 1975). Finally, full reproductive capacity is only attained at about three years of age (Fig. 3) as exemplified by an elevated (73,3\%, Table 3 ) conception rate, comparable to that for adult mares $(79,3 \%)$.

In contrast to the zebra stallion with its long pubertal interval and late age at sexual maturity when compared to the domestic horse (Smuts 1976), puberty and sexual maturity in the zebra mare occur at roughly the same age as they do in horse mares. According to Cupps, Anderson and Cole (1969) the pubertal interval in the domestic horse mare extends from eight to 20 months. Nishikawa and $\mathrm{Hafez}$ (1962) state that puberty is attained at between 15 and 18 months, while Sugie and Nishikawa (1954) give 16 to 17 months and Belonje (1958) 12 to 24 months. In the case of donkey mares, Kupfer (1928) found that ovulation commenced at one year of age. Sexual maturity on the other hand is reported to occur at 20 months (Sugie and Nishikawa 1954) and 25 to 28 months (Nishikawa and Hafez 1962) in the horse mare, and at 24 to 30 months in the donkey mare (Kupfer 1928).

\section{The mating and foaling season}

As is the case with the zebra stallion (Smuts 1976), sexual activity in the mare is largely seasonal (Fig. 6) with the majority of conceptions and births occurring in the summer (wet) season. The zebra is thus similar to most seasonal breeding species in that the mating season is initiated at such a time that environmental conditions are optimal at parturition, when both mother and offspring are most susceptible to detrimental effects (Sadleir 1969). In this species mating takes place very 
soon after parturition (8-9 days) and for all practical purposes they could be regarded as occurring at the same time (bearing in mind that the gestation period is just over a year or \pm 375 days).

From Table 4 it can be seen that peak foaling normally occurs in January ( 3 years out of 4 ) followed by December and then February. A similar pattern is obtained when studying the foaling season as obtained using embryos and foetuses (Table 5). In addition to these, an average of $44,6 \%$ of the total foal crop is produced during December and January (Table 6) and an average of $85,2 \%$ during the sixmonth summer season (October to March), i.e. only 14,8\% of foals are born during the dry winter months. Table 6 further indicates that on average $85,6 \%$ of all conceptions take place during the summer. This again correlates well with the previously-mentioned foaling activity and proves that both mating and foaling are synchronised with the summer season when green food is normally freely available. In the case of the domestic horse it has also been proved that reproductive activity is largely confined to the wet season (Quinlan, van Rensburg and Steyn 1951; van Niekerk 1967).

From Fig. 6 it is clear that conception and foaling closely follow daylight hours, temperature and rainfall. Daylight hours and temperature are, however, very constant from one year to the next, while rainfall may vary considerably. Since relative monthly conception percentages over the four-year period varied considerably, it is obvious that some factor other than daylight hours (photoperiod) or temperature must be causing the variation. When viewing the rainfall histograms it can be seen that relative monthly conception percentages follow a similar erratic trend. What in fact appears to happen may be summarised as follows: The first spring rains (usually October to November) are followed by a marked increase in conceptions. This is especially obvious when conception rate during the previous summer was low and many anoestrous mares enter the winter season (e.g. the winter for 1970 was eight months long extending from March to October and the conception rate was only $63,6 \%$ ). Here the first rains which fell in October 1970 , were followed by a rapid increase in breeding activity and consequently an increased relative monthly conception percentage. This then remained practically constant for the next four months so that 42 out of 46 adult mares collected during the ensuing winter were pregnant (conception rate $=91,3 \%$ ). The fact that relative monthly conception percentages remained so consistent between January and March is believed to be due to the good rainfall recorded during December and January and to the large numbers of non-pregnant mares which entered the 1970/7 1 breeding season.

The dependence of high relative monthly conception percentages on rainfall is best illustrated by the $1969 / 70$ summer season. During this season rainfall was extremely variable from one month to the next with only 36 and six $\mathrm{mm}$ of rain being recorded during November and January respectively. The total rainfall was also unusually low (total = 
$370,5 \mathrm{~mm}$ for October 1969 to March 1970). When viewing the corresponding relative monthly conception percentages, one finds a similar pattern in that the initially high conception for October is followed by a marked drop during November with an increase during December and January. The increase during January is probably due to the good rains $(90 \mathrm{~mm})$ experienced during December, while the drop during February is due to the poor rains $(6 \mathrm{~mm})$ of January. The erratic rainfall for this summer season also appears to have resulted in an unusually low conception rate - only $63,6 \%$. Erratic relative monthly conception percentages are probably largely due to the fact that foaling mares fail to show the normal foal heat and only do so when conditions are favourable. Ovaries taken from a sample of 11 non-pregnant mares collected during the winter of 1970 proved that 10 were in deep anoestrus, the largest follicle being 12 millimetres in diameter. Additionally there were no fresh corpora lutea (except for one specimen) but numerous very small corpora albicantia. Most of these mares had young, two- to six-month old, foals at foot. Unfortunately the monthly foaling season counts were not sensitive enough to show up the erratic state of the previous year's conception. This is partly due to the fact that field counts depict foal survival, i.e. births minus early postnatal mortality, and not merely births.

The early start of conceptions during September 1969 also demonstrates that anoestrous mares or those foaling early in the season will come on heat and conceive early if conditions are favourable.

Since the foaling season peaks illustrated in Fig. 6 have been drawn above their corresponding months and rainfall it can be seen that the foaling season also approximates rainfall. This, however, is due to the fact that the gestation period is just over 12 months long and that through the process of natural selection, mating has been geared and genetically fixed to take place during the summer months. Throughout this time the animals probably respond to a variety of environmental stimuli of which the most important are daylength, temperature, rainfall, vegetation and possibly certain social factors. Rainfall does, however, either hasten or delay the onset of breeding activity and causes a certain amount of in-season irregularity. Although rainfall may be an important stimulus, increased nutritional intake due to the growth flush following the first spring showers, is more likely to be the cause of the reproductive activity. In horses, for example, nutritional factors are considered to be responsible for irregularities in the oestrous cycle and for low fertility (Quinlan et al. 1951). Under the environmental conditions prevailing in the Karoo Midlands of South Africa, Belonje (1958) has also demonstrated that fluctuations in the commencement and duration of the breeding of thoroughbred mares was due to the condition of the mare which in turn could be ascribed to nutritional intake. In any natural area the seasonal condition of the veld is largely due to the three climatic variables, rainfall, daylight hours and temperature. However, since temperature and in particular day length are practically 
seasonal constants, only rainfall and the concomitant increase in green vegetation can cause the summer irregularities in breeding activity.

At this stage it would be impossible to decide which vegetation factors were responsible for the onset of mating activity and in-season irregularities. These reactions could, for example, be due either to increased and improved intake, to substances present in green grass, or to direct stimulation of the central nervous system via the eyes. Since any, and possibly all, of these could play a role in initiating reproductive activity, only carefully controlled experiments would be able to provide a possible solution. Although the inference has been made that oestrogenic substances present in freshly sprouting grasses stimulate breeding in the red kangaroo (Megaleia rufa) (Newsome 1966) and that some factor present in green grass is necessary for successful reproduction of rabbits (Oryctolagus cuniculus) (Myers and Poole 1962), there is little evidence to suggest that a similar state of affairs may exist in other medium-sized and large mammals. In fact oestrogenic pastures are generally held to have an adverse effect on reproduction, impairing fertility in both ewes and cows (Moule, Braden and Lamond 1963). The actions and effects of plant oestrogens and the experimental problems underlying research in this field are reviewed by Samuel (1967). He also mentions that not only is there a variation in the oestrogenic activity of plants under different environmental conditions but that larger doses of oestrogen can inhibit follicular growth by suppressing the secretion of pituitary gonadotrophins, whereas small doses may enhance follicular development. These matters are nevertheless still very much in the experimental phase and valid conclusions would be difficult to make.

The importance of photo-stimulation and temperature on the sexual periodicity of the zebra cannot, however, be overlooked. In mammals (Amoroso 1955) these two factors are known to have important influences on the regulation of the oestrous cycle and sexual behaviour. In the case of the domestic horse, Burkhardt (1947), for example, has shown in a series of controlled experiments that oestrus and ovulation followed by pregnancy could be induced in anoestrous mares by general irradiation with strong artificial light. Nishikawa, Sugie and Harada (1952) similarly were able to stimulate ovarian activity earlier in Korean ponies subjected to five hours of extra light added at the end of the day. The ovaries of mares given this treatment began to function some 65 to 80 days earlier than unlighted controls. They were also able to stimulate ovarian function in the normal non-breeding season and in both experiments induced ovarian activity was accompanied by normal fertility. Nishikawa and Horie (1952) who used similar light regimes on the stallion, reported that extra light accelerated the normal increase in semen volume and brought it forward by about two months.

The importance of season on the breeding habits of the horse is aptly demonstrated when mares transported from the Northern to the Southern hemisphere change over their times of breeding to fit the seasons in their new surroundings (Belonje 1960). 
In his study on zebra in the Ngorongoro Crater, Klingel (1965 and 1969a) states that zebra foals are born during any month of the year, the majority from October to March, with a peak in January. His distribution of foaling is also very similar to that found in the KNP and is likewise correlated with rainfall. Fairall (1968) found that zebra in the KNP foal from September to March with a peak during the period November to February. On the basis of the findings of the present study it would, however, be extremely difficult to justify the findings of Ansell (1960) whereby it is stated that July to September is the period of peak foaling in Zambia.

In summary it may be said that zebra in the Central District of the KNP are seasonal breeders with between 85 and $88 \%$ of all births and conceptions occurring during the summer months which extend from October to March. Within this interval, December and January are the peak months. In agreement with domestic horse breeds which have a defined breeding season, the zebra displays a reproductive cycle which is synchronised with the photoperiod. In this respect conception percentages rise and fall as does the length of daylight hours (and average daily temperature). Of particular importance, however, is rainfall which has a profound effect on the initiation of breeding activity and irregularities in relative monthly conception percentages within a particular season. The effect of rainfall may either be direct, or indirect via increased summer nutritional intake. It may similarly also be said that the breeding cycle of the zebra mare is most probably regulated by the interplay of a variety of environmental and possibly social factors.

\section{Conception rate and the factors affecting it}

Since the fallopian tubes of visibly non-pregnant mares were not washed out to recover any possible blastocysts, the conception rate of $79,3 \%$ must be regarded as the minimum. It is unlikely, however, that very many mares in early pregnancy were classified as non-pregnant since the conceptus should be visible by 10 to 15 days after fertilization. In the domestic horse, for example, pregnancy can be diagnosed rectally by palpating the uterine horns and by actually feeling the embryonic mass at 14 days (Van Niekerk 1965). Assuming that all embryos less than 15 days old were overlooked in the present study, it was calculated (Smuts 1974a) that the average conception rate would rise from 79,3 to 82,7 percent.

A conception rate of $79,3 \%$ to $82,7 \%$ for the four study years would appear fairly average as a wide range of rainfall and other climatic conditions were experienced during this period. In this respect the 1968/69 summer season may be regarded as being normal, while the 1969/70 and 1970/71 summer seasons were dry with expecially erratic conditions prevailing during the $1969 / 70$ season. In contrast to these, the summer of $1971 / 72$ was extremely wet with the highest rainfall in 32 years being experienced in the Tshokwane/Satara area (Fig. 6) where all material was collected. 
The conception rates for young mares given in Table 3 indicate that the adult rate is achieved just after three years of age. Further breakdown of conception data into the various adult age classes (Table 7) proves that there are no adult age-specific fertility rate differences and that mares remain fertile into old age. The conception rate differences for the adult age classes in Table 7 are due to unequal sampling of the age classes during the different years of collection.

Conception rates for the four non-breeding seasons experienced during the study period (Table 8) indicate that conception rate varies considerably from one year to the next. These variations represent the reaction of zebra to their environment. When viewing the data on summer rainfall and the conception rates for the non-breeding season (Fig. 6) it can be seen that poor summer rains are not necessarily followed by a low conception rate. In fact the highest conception rates of $88,6 \%$ (1966) and 91,3\% (1971) were recorded after the driest summers. During these summers (October to March) 350 and $333 \mathrm{~mm}$ of rain were recorded respectively (average summer rainfall $=425 \mathrm{~mm}$ ). Similarly the high summer rainfall experienced during 1971/72 (759 $\mathrm{mm}$ - highest in 32 years) was followed by a below average conception rate while the almost average rainfall for the 1968/69 summer $(414 \mathrm{~mm})$ also produced a sub-average conception rate. Lastly the $1969 / 70$ summer season with its erratic total rainfall of $371 \mathrm{~mm}$ produced the lowest ever conception rate of $63,6 \%$. Conception success must obviously be due to some factor(s) other than total summer precipitation.

The results of the present study indicate that in addition to summer precipitation, conception rate may be influenced by numerous and frequently interrelated factors. Firstly the actual months during which the greatest proportion of the summer rains fall, appears to be important. In this respect poor or erratic rains experienced during the months of peak mating activity, namely November to February, may precipitate low conception rates. This was particularly obvious during the 1969/70 breeding season when very little rain was recorded during November and January. The $70 \%$ conception rate recorded during the nonbreeding season of 1969 may also be partly ascribed to the relatively poor rainfall of January and February 1969 which are normally the months of peak breeding. In contrast, good and regular summer rains do not necessarily produce a high conception rate. During the 1971/72 summer, for example, high rainfall $(759 \mathrm{~mm})$ was followed by a relatively low conception rate $(75,6 \%)$. This could either be due to excessively wet conditions or it may be linked with the unusually high conception rate of the previous year.

The high conception rate $(91,3 \%)$ recorded during the nonbreeding season of 1971 warrants special discussion since quite a different factor, namely the effective length of the preceding non-breeding season (winter), appears to have been operative. From Fig. 6 it can be seen that 1970 was made up of an unusually long winter extending from February 
to October ( 8 months). Conception rate recorded during this period was very low $(63,6 \%)$ with the result that a large number of nonpregnant mares were being subjected to an extended season of sexual inactivity. The below average rainfall registered between October 1970 and April 1971 was, however, sufficient to stimulate mating activity to the extent that $91,3 \%$ of all recently foaled and non-pregnant mares were mated. These results may be explained on the basis that anoestrous mares subjected to extended winters are more likely to come into oestrus and conceive during the ensuing mating season (summer) than those subjected to short winters. The same condition may apply to pregnant mares. It thus appears that animals deprived of optimal conditions for extended periods are more likely to respond to these when they do occur. One may therefore postulate that this type of deprivation causes a lowered sexual threshold and consequently more vigorous summer mating activity and increased conception rates.

When compared to other associated herbivore species, and in particular potential competitors such as the wildebeest, the average adult conception rate of $79,3 \%$ for zebra is decidedly low. The same applies to the adult conception rate range of 63,6 to 91,3 percent. In the Central District of the KNP adult wildebeest cows (two to $16+$ years old) have an average conception rate of $92 \%(n=125)$ while that for one to two-year olds is $32 \%(\mathrm{n}=31)$ (Braack 1973). In the Serengeti wildebeest, Watson (1969) reports an average adult conception rate of $96 \%$ with an average of $37 \%$ for cows in their first reproductive year and $83 \%$ for cows in their second year. It is thus obvious that the wildebeest which can conceive successfully during its second year (one year and four months) (Watson 1969), generally has a greater breeding potential than the zebra which only conceives successfully during its third year (Tables 3 and 7). An average adult conception rate difference of $12 \%$ for the two species in the KNP is further evidence for the greater breeding potential of the wildebeest. When comparing zebra and impala, for which adult fertility rates of 97\% (Dasmann and Mossman 1962) and adult lambing rates of 90\% (Fairall 1969) have been registered, it becomes clear that in addition to conception rate, success of the zebra population must also depend on increased postnatal survival.

It must, however, be borne in mind that successive conceptions in the zebra will tend to occur approximately 20 days later during each successive year. This is due to an average gestation period of 375 days, followed by a foal heat and possible conception about 10 days after parturition. This would eventually put a mare out of phase with the normal mating season (October to March) and since mares stand a reduced chance of conceiving during the winter (April to September), they would only come on heat during the following summer (approximately six months later). Since one would expect a certain percentage of mares to be out of phase each year, it would undoubtedly have an effect on the overall conception rate of the population. This pheno- 
to October ( 8 months). Conception rate recorded during this period was very low $(63,6 \%)$ with the result that a large number of nonpregnant mares were being subjected to an extended season of sexual inactivity. The below average rainfall registered between October 1970 and April 1971 was, however, sufficient to stimulate mating activity to the extent that $91,3 \%$ of all recently foaled and non-pregnant mares were mated. These results may be explained on the basis that anoestrous mares subjected to extended winters are more likely to come into oestrus and conceive during the ensuing mating season (summer) than those subjected to short winters. The same condition may apply to pregnant mares. It thus appears that animals deprived of optimal conditions for extended periods are more likely to respond to these when they do occur. One may therefore postulate that this type of deprivation causes a lowered sexual threshold and consequently more vigorous summer mating activity and increased conception rates.

When compared to other associated herbivore species, and in particular potential competitors such as the wildebeest, the average adult conception rate of $79,3 \%$ for zebra is decidedly low. The same applies to the adult conception rate range of 63,6 to 91,3 percent. In the Central District of the KNP adult wildebeest cows (two to $16+$ years old) have an average conception rate of $92 \%(n=125)$ while that for one to two-year olds is $32 \%(\mathrm{n}=31)$ (Braack 1973). In the Serengeti wildebeest, Watson (1969) reports an average adult conception rate of $96 \%$ with an average of $37 \%$ for cows in their first reproductive year and $83 \%$ for cows in their second year. It is thus obvious that the wildebeest which can conceive successfully during its second year (one year and four months) (Watson 1969), generally has a greater breeding potential than the zebra which only conceives successfully during its third year (Tables 3 and 7). An average adult conception rate difference of $12 \%$ for the two species in the KNP is further evidence for the greater breeding potential of the wildebeest. When comparing zebra and impala, for which adult fertility rates of 97\% (Dasmann and Mossman 1962) and adult lambing rates of 90\% (Fairall 1969) have been registered, it becomes clear that in addition to conception rate, success of the zebra population must also depend on increased postnatal survival.

It must, however, be borne in mind that successive conceptions in the zebra will tend to occur approximately 20 days later during each successive year. This is due to an average gestation period of 375 days, followed by a foal heat and possible conception about 10 days after parturition. This would eventually put a mare out of phase with the normal mating season (October to March) and since mares stand a reduced chance of conceiving during the winter (April to September), they would only come on heat during the following summer (approximately six months later). Since one would expect a certain percentage of mares to be out of phase each year, it would undoubtedly have an effect on the overall conception rate of the population. This pheno- 
menon would also partly account for the low average conception rate found in zebra when compared to other herbivores with gestation periods shorter than one year.

Unfortunately it is difficult to compare conception rates in the zebra with the domestic horse where a variety of additional factors may influence conception. In certain areas, however, horses are allowed free range and association with stallions and in these cases conception rate is decidedly higher than in the zebra. Day (1939), for example, mention's that ponies running wild have. a conception rate of $95 \%$ in Britain. In South Africa, van Rensburg and van Heerden (1953) obtained a conception rate of $87,5 \%$ for free roaming mares. These higher rates could partly be due to the shorter gestation period in domestic horses (329-345 days; Asdell 1946), with the result that animals are less likely to become out of phase with their normal mating season than are zebra. Additionally supplementary feeds during times of hardship would favour the domestic equine over the wild zebra.

\section{Ovarian activity during the oestrus cycle}

From Table 9 it can be seen that the mean mass and dimensions of the pro-oestrous ovary exceed those of the other three phases. Similarly this ovary contains the follicle with the greatest diameter.

Occasionally late dioestrous ovaries are difficult to distinguish from pro-oestrous specimens and they may attain a mass of almost $40 \mathrm{~g}$ due to follicular development. The important difference between the various phases of the oestrous cycle, however, lies in the development of the corpus luteum. In pro-oestrous ovaries there may or may not be a corpus luteum with a diameter in excess of $10 \mathrm{~mm}$, while those with diameters of less than $10 \mathrm{~mm}$ are generally very old and quite possibly the remains of corpora lutea from the previous breeding season. Regressing corpora lutea generally have a very characteristic pear shape, the thin tip being in apposition to the ovarian fossa. As regression progresses the body becomes darker in colour (ochre in formalin-fixed specimens) and thinner, until a very narrow streak of scar tissue remains (the corpus albicans).

During metoestrus, the corpus luteum attains its maximum size (32 mm) after which it gradually regresses. During dioestrus regression continues, the corpus luteum, however, still being present by the time the succeeding cycle commences. In this respect the zebra mare is similar to the domestic horse (Hammond and Wodzicki 1941) in that the corpus luteum of a previous generation (cycle) can exist, although reduced in size, side by side with one of the last generation and a third from the new generation. In addition, corpora lutea may continue to regress for at least one year and during these stages they assume the thin dark tapering shape $( \pm 10 \times 2 \mathrm{~mm})$ illustrated in the anoestrous ovaries (Fig. 7). Similar structures are, however, also present in the other phases of the cycle. 
According to Rowlands (in litt.), equids differ characteristically from other mammals in that during early pregnancy a new crop of follicles is produced which ovulate to form secondary corpora lutea as the main source of progesterone, following the regression of the primary corpus luteum. This state of affairs differs from hystricomorph rodents and some primates where follicles luteinise at the same time, or after other follicles ovulate to form the primary corpus luteum of pregnancy. These bodies persist as accessory corpora lutea (Rowlands in litt.). The word "secondary" is therefore used to describe corpora lutea which have formed during pregnancy through luteinisation of ruptured follicles, while accessory corpora lutea describe the bodies formed through luteinisation of unruptured follicles.

By referring to Fig's 8,9 and 10 it can be seen that ovarian activity is largely in abeyance between approximately 190 days and full term pregnancy. During the latter half of pregnancy the ovary is typified by the absence of follicles with diameters greater than 12 millimetres. Small regressing follicles may, however, be quite abundant (Table 10), their numbers generally varying from one animal to the next. In some near-term specimens over 50 tiny (one to $10 \mathrm{~mm}$ ) follicles were counted, while in others there were only four or five.

In contrast to the latter half of pregnancy, the first 190 days show a number of interesting phases of activity. Unfortunately few specimens were available for the first 60 days and these additionally indicated that there was considerable variation between individual mares. Although the small sample precludes reliable conclusions, it would appear that ovarian activity increases gradually after conception to reach a peak between the 40th and 110th days of pregnancy (Fig's 9 and 10). This peak in turn appears to be correlated with the secretion of serum gonadotrophin (Smuts 1974a).

Data collected from my series of pregnant mares are very similar to those obtained by King (1965) from 20 pregnant Grant's zebra mares shot in East Africa. He found that large $(20 \mathrm{~mm})$ follicles were present up to 119 days of pregnancy after which their diameter decreased. The only secondary corpus luteum he could positively identify was at 98 days (as was one of the cases in the present study). He also mentions that the corpus luteum of pregnancy begins to regress at 22 weeks of pregnancy and that the presence of a large corpus luteum for more than five months was probably a result of the formation of fresh corpora lutea (secondary corpora lutea) during early pregnancy. In the present study, however, mares lacking secondary corpora lutea frequently still had the corpus luteum of pregnancy visible after 200 days of pregnancy and in a few instances up to 300 days of pregnancy.

When compared to mares of various domestic horse breeds, it is obvious that the ovarian cycle is very similar in the zebra mare. Differences, however, firstly include the dimensions and mass of the glands in the two species. In the horse, single ovaries frequently have a mass 
of up to $80 \mathrm{~g}$ (Sisson and Grossman 1953) with the normal mass ranging between 40 and $70 \mathrm{~g}$ (Hammond and Wodzicki 1941). During early pregnancy when follicular activity is high, the ovaries may attain a mass (paired) of over $150 \mathrm{~g}$ (van Rensburg and van Niekerk 1968), while in the zebra mare the greatest mass (paired) recorded was $89,1 \mathrm{~g}$ in a 69-day pregnant specimen. Similarly the length of the ovaries in the horse is greater, being from 5,5 to eight $\mathrm{cm}$ (Hammond and Wodzicki 1941), while in the zebra they range from 2,5 to $7,4 \mathrm{~cm}$ in adult individuals (Tables 9 and 10). In addition to these, ovarian activity in Burchell's zebra and the horse also differs in certain other respects. The stimulus for follicular development and secondary ovulations during early pregnancy appears to be greater in the horse (Cole, Howell and Hart 1931; King 1966). Secondary ovulations and the formation of secondary corpora lutea also appear to occur at an earlier date in the horse mare. Day (1940), for example, observed the occurrence of ovulation on the 23rd day of pregnancy, while Allen (1971) found that the average time of the first ovulation was 52,5 days and that for second ovulations, 66 days. Van Rensburg and van Niekerk (1968) also found that the rise in follicular activity after the 40th day resulted in secondary ovulations but that corpora lutea formed after the 50th day were produced by luteinization of unruptured follicles. Rowlands (1949), however, feels that early luteal structures in his material were all formed from follicles that had ovulated. The early formation of secondary corpora lutea in the horse is, however, by no means a rule, as Allen (1971) recorded two relatively late in gestation (after 80 days). All these observations indicate that not only is there a tremendous variation between breeds, but even within breeds from the same area.

Development of the corpus luteum of pregnancy is similar in both species, the body reaching its maximum size at 14 days of pregnancy in the horse (Harrison 1946). According to van Rensburg and van Niekerk (1968), the primary corpus luteum of pregnancy in the horse remains quite active at least up to the third month of pregnancy. In Grevy's zebra, the corpus luteum of pregnancy was found to remain functional for at least 60 days according to King (1966) who also felt that the relatively few secondary corpora lutea produced in zebra species (Burchell's and Grevy's) was compensated for by an extended period of activity of the corpus luteum of pregnancy. The more recent chemical assays undertaken by van Rensburg and van Niekerk (1968), however, tend to invalidate these observations since they found that activity continued up to three months and concluded that secondary corpora lutea in the horse were essentially supplementary sources of progesterone.

As is the case with the zebra mare in the present study, the horse appears to display differential ovarian activity. Hancock (1948) and Arthur (1958), for example, found that 52,2 and 63,0\% respectively of ovulations were from the left ovary in cycling mares $(60 \%$ in the present study). In pregnant horse mares similar results have been obtained and here Allen (1971) reports a percentage of 53 for ovulations 
from the left ovary, while Osborne (1966) recorded a significant 55,6\% from a total of 3056 single and multiple ovulations.

In contrast to the zebra mare where slightly more implantations were recorded from the left uterine horn $(55,6 \% ; \mathrm{n}=63$ mares), more implantations appear to occur in the right horn of the horse (see Amoroso, Hancock and Rowlands 1948, and Hancock 1948). Transuterine migration, however, occurs at approximately the same rate in both species - 41,7\% in the zebra and 40,0 and 50,0\% in the horse (Hancock 1948 and Amoroso et al. 1948, respectively). As is the case with the zebra, most migrations in the horse are from the left horn of the uterus to the right.

\section{Twinning}

In contrast to the domestic horse which occasionally produces viable twins (Asdell 1946), a zebra mare has not yet been observed with twins. In fact, the only record of a twin conception is given by Wackernagel (1965). These were aborted in the eighth month. In the domestic horse the incidence of twin pregnancies varies between one and five per cent (Nishikawa and Hafez 1962). Usually, however, one of the twins dies before birth and twin births occur only in very few cases. Hancock (1948) has also shown that although twin conceptions may occur in up to $20,8 \%$ of pregnancies, foetal resorption may be high, especially before the 70th day of pregnancy. In this respect he quotes live twin birth rates of between 0,5 and 1,1\%. Klingel (1965 and 1969a) also mentions that no twin births have been recorded from zebra in the wild, while the absence of twin conceptions in the sample of 215 pregnant mares examined during the present study supports his observations. King (1965) also found no evidence of twins in the 20 pregnancies he examined. The zebra, in common with other large African herbivores, is thus a monotocous species.

\section{Reproductive senescence}

In the sample of 236 adult mares examined, the oldest two were estimated to be 17 to 18 years old (Table 7). Both these specimens were pregnant. Since free-ranging zebra in the KNP seldom survive to over 20 years of age (Smuts 1974b) it is very unlikely that reproductive senescence ever occurs in the population. This may, however, be a factor in zoological gardens where authenticated ages of up to 28 years have been recorded (Flower 1931).

\section{Acknowledgements}

The author is particularly indebted to the following people and instances: The Chief Director of National Parks, Dr. R. Knobel and the National Parks Board of Trustees under whose auspices this study was undertaken. Professor J. du P. Bothma, Dr. U. de V. Pienaar, Dr. J. 
Hanks, Dr. J. F. W. Grosskopf and Dr. W. H. Gerneke who reviewed parts of my original D.Sc. dissertation. Members of the research and management sections in the KNP who assisted with various aspects of the field work. My parents and my wife for assistance and encouragement throughout the duration of the project.

\section{REFERENCES}

ALLEN, W. E. 1971. The occurrence of ovulation during pregnancy in the mare. Vet. Rec. 88:508-509.

AMOROSO, E. C. 1955. Hormone control of the oestrous cycle. Vet. Rec. 67:1072-1084.

AMOROSO, E. C., J. L. HANCOCK and I. W. ROWLANDS. 1948. Ovarian activity in the pregnant mare. Nature, Lond. 161:355-356.

AMOROSO, E. C. and I. W. ROWLANDS. 1951. Hormonal effects in the pregnant mare and foetal foal.J. Endocrinol. 7:50-53.

ANSELL, W. F. H. 1960. The breeding of some larger mammals in Northern Rhodesia. Proc. zool. Soc. Lond. 134 :251-274.

ARTHUR, G. H. 1958. An analysis of the reproductive function of mares based on post-mortem examination. Vet. Rec. 70:682-686.

ASDELL, S. A. 1946. Patterns of Mammalian Reproduction. New York: Comstock Publishing Company Inc.

BELONJE, C. W. A. 1949. Observations on reproduction in the thoroughbred mare.J. S. Afr. vet. med. Ass. 20:21-33.

BELONJE, C. W. A. 1958. Fertility and infertility of thoroughbred mares under environmental conditions prevailing in the Karoo Midlands of South Africa. D.V.Sc. thesis, Faculty of Vet. Sc., Univ. of Pretoria. (unpublished).

BELONJE, C. W. A. 1960. The physiology of reproduction in the mare with special reference to the thoroughbred.J. S. Afr. vet. med. Ass. $31: 115-128$.

BENESCH, F. and J. WRIGHT. 1957. Veterinary Obstetrics. London: Bailliers, Tindall and Cox.

BRAACK, H. H. 1973. Population dynamics of the blue wildebeest, Connochaetes taurinus taurinus (Burchell, 1823) in the Central District of the Kruger National Park. Project report submitted to the Univ. of Rhodesia. 85 pp. (unpublished).

BURKHARDT, J. 1947. Transition from anoestrus in the mare and the effects of artificial lighting. J. agric. Sci. 37:64-68.

COLE, H. H., G. H. HART, W. R. LYONS and H. R. CATCHPOLE. 1933. The development and hormonal content of foetal horse gonads. Anat. Rec. 56:275-292.

COLE, H. H., C. E. HOWELL and G. H. HART. 1931. The changes occurring in the ovary of the mare during pregnancy. Anat. Rec. 49:199-209. 
CUPPS, P. T., L. L. ANDERSON and H. H. COLE. 1969. The estrous cycle. Pages 217-250 in "Reproduction in Domestic Animals", 2nd ed. Eds. H. H. COLE and P. T. CUPPS. New York: Academic press.

DASMANN, R. F. and A. A. MOSSMAN. 1962. Population studies of impala in Southern Rhodesia. J. Wildl. Mgmt 26:262-268.

DAY, F. T. 1939. Some observations on the causes of infertility in horse breeding. Vet. Rec. 51:581-587.

DAY, F. T. 1940. Clinical and experimental observations on reproduction in the mare. J. agric. Sci. 30:244-261.

DONOVAN, B. T. 1966. Control of follicular growth and ovulation. Pages 3-26 in "Reproduction in the Female Mammal". Eds. G. E. LAMMING and E. C. AMOROSO. London: Butterworth and Co.

DU PLESSIS, J. L. 1964. Some observations and data in thoroughbred breeding. J. S. Afr. vet. med. Ass. 35:215-221.

ECKSTEIN, P. and S. ZUCKERMAN. 1962. Morphology of the reproductive tracts. Pages 43-155 In 'Marshall's Physiology of the Reproduction", Vol. 1(1). 3rd ed. Ed. A. S. PARKES. London: Longmans.

FAIRALL, N. 1968. The reproductive seasons of some mammals in the Kruger National Park. Zool. afr. 3:189-210.

FAIRALL, N. 1969. The use of the eye lens technique in deriving the age structure and life table of an impala (Aepyceros melampus) population. Koedoe 12:90-96.

FLOWER, S. S. 1931. Contribution to our knowledge of the duration of life in vertebrate animals. V. Mammals. Proc. zool. Soc. Lond. 101: 145-235.

HAMMOND, J. and K. WODZICKI. 1941. Anatomical and histological changes during the oestrous cycle in the mare. Proc. $R$. Soc. Series B. 858. 130:1-23.

HANCOCK, J. L. 1948. Notes on oestrus, ovulation and pregnancy in the mare. Vet. Rec. 60:679-682.

HARRISON, R. J. 1946. The early development of the corpus luteum in the mare. J. Anat. Lond. 80:160-166.

HUGGETT, A. ST. G. and W. F. WIDDAS. 1951. The relationship between mammalian foetal weight and conception age. J. Physiol. 114 : 306-317.

IMES, G. D. and G. L. SMUTS. 1975. Gross and microscopic observations of ovarian abnormalities from five Burchell's zebra, Equus burchelli antiquorum, Smith 1841. OnderstepoortJ. Vet Res. 42:109-116.

JOUBERT, D. M. 1963. Puberty in female farm animals. Anim. Breed. Abstr. 31:295-306.

KENNETH, J. H. and G. R. RITCHIE. 1953. Gestation periods: a table and bibliography. Technical Communications No. 5 of the Commonwealth Bureau of Animal Breeding and Genetics, Edinburgh.

KING, J. M. 1965. A field guide to the reproduction of the Grant's zebra and Grevy's zebra. E. Afr. Wildl.J. 3:99-117. 
KING, J. M. 1966. Comparative Aspects of Reproduction in the Equidae. Ph.D. Thesis, University of Cambridge.

KLINGEL, H. 1965. Notes on the biology of the plains zebra (Equus quagga boehmi Matschie). E. Afr. Wildl.J. 3:86-88.

KLINGEL, H. 1967. Soziale Organisation und verhalten freilebender Steppenzebras. Z. Tierpsychol. 24:580-624.

KLINGEL, H. 1969a. Reproduction in the plains zebra (Equus burchelli boehmi): Behaviour and ecological factors. J. Reprod. Fert. 6: 339-345.

KLINGEL, H. 1969b. The social organisation and population ecology of the plains zebra (Equus quagga). Zool. afr. 4:249-263.

KLINGEL, H. and U. KLINGEL. 1965. Die Geburt eines Zebras (Equus quagga boehmie Matschie). Z. Tierpsychol. 23:72-76.

KUPFER, M. 1928. The sexual cycle of female domesticated mammals. Dept. of Agric. 13th and 14th Reports of the Director of Vet. Education and Research, Part. I.: 1211-1270.

MOULE, G. R., A. W. H. BRADEN and D. R. LAMOND. 1963. The significance of oestrogens in pasture plants in relation to animal production. Anim. Breed. Abstr. 31:139-157.

MYERS, K. and W. E. POOLE. 1962. A study of the biology of the wild rabbit, Oryctolagus cuniculus (L), in confined populations III. Reproduction. Austr.J. Zool. 10:225-267.

NEWSOME, A. E. 1966. The influence of food on breeding in the red kangaroo in Central Australia. CSIRO Wildl. Res. 11:187-196.

NISHIKAWA, Y. and E. S. E. HAFEZ. 1962. The reproduction of horses. Pages 266-276 in "Reproduction in Farm Animals". Ed. E.S.E. HAFEZ. Philadelphia: Lea and Febiger.

NISHIKAWA, Y. and T. HORIE. 1952. Studies on the effect of daylength on the function of the testes. Bull. natn. Inst. agric. Sci. (Japan) Ser. G. 3: 45. From: Anim. Breed. Abstr. 22: Abs. No. 439.

NISHIKAWA, Y., T. SUGIE and N. HARADA. 1952. Studies on the effect of daylength on reproductive function in horses. I. Effect of daylength on the function of the ovary. Bull. natn. Inst. agric. Sci., Japan Ser. G. 3: 35-44. From: Anim. Breed. Abstr. 22: Abs. No. 436.

OSBORNE, V. E. 1966. An analysis of the pattern of ovulation as it occurs in the annual reproductive cycle of the mare in Australia. Aust. vet.J. 42:149-154.

QUINLAN, J., S. W. J. VAN RENSBURG and H. P. STEYN. 1951. The oestrous cycle of the mare when maintained under stable conditions with restricted exercise at Onderstepoort. Onderstepoort J. vet. Res. 25:105-119.

ROWLANDS, I. W. 1949. Serum gonadotrophin and ovarian activity in the pregnant mare. J. Endocrin. 6:184-191.

SADLEIR, R. M. F. S. 1969. The Ecology of Reproduction in Wild and Domestic mammals. London: Methuen and Co. Ltd.

SAMUEL, D. E. 1967. A review of the effects of plant estrogenic substances on animal reproduction. OhioJ. Sci. 67:308-312. 
SATO, S. and S. HOSHI. 1934. Studies on reproduction in the mare. III. The oestrous duration and oestrous cycle. J. Jap. Soc. vet. Sci. $13: 237-251$.

SISSON, S. and J. D. GROSSMAN. 1953. Pages 581-594 in "The Anatomy of the Domestic Animals". Fourth ed. revised. Philadelphia: W. B. Saunders Company.

SMUTS, G. L. 1972. Seasonal Movements, Migration and Age Determination of Burchell's Zebra (Equus burchelli antiquorum, H. Smith, 1841) in the Kruger National Park. M.Sc. Wildl. Mgmt. thesis, University of Pretoria. 170 pp.

SMUTS, G. L. 1974a. Growth, reproduction and population characteristics of Burchell's zebra (Equus burchelli antiquorum, H. Smith, 1841) in the Kruger National Park. D.Sc. Wildl. Mgmt. dissertation. University of Pretoria. $268 \mathrm{pp}$.

SMUTS, G. L. 1974b. Age determination in Burchell's zebra (Equus burchelli antiquorum) from the Kruger National Park. J. sth Afr. Wildl. Mgmt Ass., 4:103-115.

SMUTS, G. L. 1975. Pre- and post-natal growth phenomena of Burchell's zebra (Equus burchelli antiquorum). Koedoe 18:69-102.

SMUTS, G. L. 1976. Reproduction in the zebra stallion (Equus burchelli antiquorum) from the Kruger National Park. Zool. afr. (in press).

SUGIE, T. and Y. NISHIKAWA. 1954. Studies on sexual maturity in the mare. Bull. natn. Inst. agric. Sci. Tokyo (Chiba). G. 8:151-159. From Anim. Breed. Abs. 23. Abs. No. 1602.

TRUMLER, E. 1958. Beobachtungen an den Böhmzebras des George von Opel Freigeheges für Tierforschunge. V: 1. Das Paarungsverhalten. Saügetierk. Mitt. 6:1-48.

VAN NIEKERK, C. H. 1965. The early diagnosis of pregnancy, the development of the foetal membranes and nidation in the mare. Jl. S. Afr. vet. med. Ass. 36:483-488.

VAN NIEKERK, C. H. 1967. Pattern of the oestrous cycle of mares. $J l$. S. Afr. vet. med. Ass. 38:299-307.

VAN RENSBURG, S. W. J., and J. S. VAN HEERDEN. 1953. Infertility in mares caused by ovarian dysfunction. Onderstepoort J. vet. Res. $26: 285-313$.

VAN RENSBURG, S. J. and C. H. VAN NIEKERK. 1968. Ovarian function, follicular oestradiol-17B and luteal progesterone and 20 hydroxy-pregn-4-en-3-one in cycling and pregnant equines. Onderstepoort J. vet. Res. 35:301-318.

WACKERNAGEL, H. 1965. Grant's zebra (Equus burchelli boehmi) at Basle zoo - a contribution to breeding biology. Int. Zoo Yb. 5:38-41.

WATSON, R. M. 1969. Reproduction of wildebeest (Connochaetes taurinus albojubatus Thomas) in the Serengeti region, and its significance to conservation. J. Reprod. Fert. Suppl. 6:287-310.

WITHERSPOON, D. M. and R. B. TALBOT. 1970. Ovulation site in the mare. J. Am. vet. med. Assn. 157:1452-1459. 